Wright State University

CORE Scholar

\title{
Tree Seedling Establishment Under the Native Shrub, Asimina Triloba
}

\author{
Marilyn Cabrini Baumer \\ Wright State University
}

Follow this and additional works at: https://corescholar.libraries.wright.edu/etd_all

Part of the Biology Commons

\section{Repository Citation}

Baumer, Marilyn Cabrini, "Tree Seedling Establishment Under the Native Shrub, Asimina Triloba" (2007). Browse all Theses and Dissertations. 134.

https://corescholar.libraries.wright.edu/etd_all/134

This Thesis is brought to you for free and open access by the Theses and Dissertations at CORE Scholar. It has been accepted for inclusion in Browse all Theses and Dissertations by an authorized administrator of CORE Scholar. For more information, please contact library-corescholar@wright.edu. 
TREE SEEDLING ESTABLISHMENT UNDER THE NATIVE SHRUB, ASIMINA TRILOBA

A thesis submitted in partial fulfillment of the requirements for the degree of Master of Science

By

MARILYN CABRINI BAUMER

B. A., University of Dayton, 1978

M. A., University of Dayton, 1982

2007

Wright State University 
WRIGHT STATE UNIVERSITY

SCHOOL OF GRADUATE STUDIES

$\underline{\text { June } 14,2007}$

I HEREBY RECOMMEND THAT THE THESIS PREPARED UNDER MY SUPERVISION BY Marilyn Cabrini Baumer ENTITLED Tree Seedling Establishment under the Native Shrub, Asimina triloba, BE ACCEPTED IN PARTIAL FULFILLMENT OF THE REQUIREMENTS FOR THE DEGREE OF Master of $\underline{\text { Science. }}$

James R. Runkle, Ph.D.

Thesis Advisor

David Goldstein, Ph.D.

Department Chairman

Committee on Final Examination:

Don Cipollini, Ph.D.

Yvonne Vadeboncoeur, Ph.D.

Joseph F. Thomas, Jr., Ph.D.

Dean of the School of Graduate Studies 


\begin{abstract}
Baumer, Marilyn Cabrini. M.S., Department of Biological Sciences, Wright State University, 2007. Tree Seedling Establishment Under the Native Shrub, Asimina Triloba.
\end{abstract}

Species that form forest understory layers affect canopy tree seedling establishment worldwide. In the Eastern United States, shrub understories like Rhododendrom maximum, a native evergreen species, and Lonicera maackii, an exotic, invasive species, diminish tree seedling survival. I compared the density and survival of canopy tree seedlings under and outside patches of the native shrub, Asimina triloba (L.) Dunal (Annonaceae) (pawpaw). I also conducted a manipulative experiment to determine whether above ground or below ground competition was more important in seedling growth and survival. Above ground competition was manipulated by tying back the leaves of the pawpaw and below ground competition was manipulated by trenching the perimeter of the study plots. Tree seedling density was approximately three times greater outside pawpaw patches than under pawpaw over the range of sites. Seedlings under pawpaw were both younger and shorter than those outside of pawpaw. Survival varied by species. Acer saccharum seedlings were about one and a half times more likely to survive outside pawpaw than under pawpaw. Prunus serotina seedlings were about three times more likely to survive outside pawpaw than under pawpaw. In contrast, pawpaw did not affect the survival of Fraxinus spp. seedlings. Differing survival rates may reflect characteristics related to the species shade tolerance. Light (measured by canopy densiometer) was greater outside pawpaw than under pawpaw. No significant differences in moisture levels were detected; however, at three of the four sites, moisture 
was greater under pawpaw than outside of pawpaw. The combination of above ground and below ground factors was more important in the survival and growth (measured by biomass) of planted A. saccharum seedlings under pawpaw than either above ground or below ground factors alone. Given that conditions such as elevated deer herbivory and tree diseases may provide opportunities for pawpaw to expand, continued attention to the pawpaw understory is warranted. 


\section{TABLE OF CONTENTS}

Page

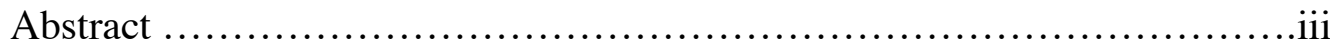

Table of Contents...................................................

List of Figures................................................. vii

List of Tables..................................................viii

Appendices.......................................................

Acknowledgements...................................................

Introduction.........................................................

Methods........................................................6

Study Sites...................................................6

Species Description.........................................8

Field Study................................................ 10

Manipulative Experiment.................................... 12

Results......................................................... 14

Field Study..............................................14

Seedling Density....................................14

Height and Age Characteristics...........................14

Resource Availability.................................15

Survival..............................................16

Manipulative Experiment....................................16

Survival............................................16

Seedling Biomass....................................17 
Discussion........................................................ 18

Resource Limitations.........................................21

Forest Dynamics..........................................24

Pawpaw Understory Dynamics..............................26

Future Research...........................................27

Literature Cited......................................................47 


\section{LIST OF FIGURES}

Figure

Page

1. Average seedling density v. differences in seedling densities outside and under pawpaw....

2. Comparisons of seedling percentages by A) height and B) age classes under pawpaw and not under pawpaw.

3. Comparisons of A) overstory density and B) moisture levels under and not under pawpaw.......................................... 31

4. Effects of trenching and tie-back of pawpaw on survival of Acer saccharum seedlings.......................................32

5. Effects of trenching and leaf treatment on total seedling biomass, leaf biomass, root biomass and stem biomass........................33 


\section{LIST OF TABLES}

Table

Page

1. Summary of the relationships among seedling survival, pawpaw, species, and site from logistic regression analysis.................. 34

2. Summary of effects of pawpaw and site by species on survival of tree seedlings from logistic regression analysis.....................35

3. Percent annual survival by species............................ 36

4. Summary of 2-way ANOVAs of the growth response of Acer saccharum seedlings to leaf treatments.......................37 
Maps of Study Sites

Aullwood Gardens...............................................38

Caesar Creek State Park...........................................39

Englewood MetroPark...........................................40

Hueston Woods State Park....................................41

Twin Creek MetroPark.........................................42

Wright State University Woods................................43

Tables

A1. Average stem density $/ \mathrm{m}^{2}$ for all study sites......................44

A2. Number of surviving A. saccharum seedlings for two replicates of four treatments............................................. 45

A3. Mean weight (g)/ plant for total seedling biomass, leaf biomass, root biomass, and stem biomass for four treatments and two plots/treatment. .46 


\section{ACKNOWLEDGEMENTS}

Completion of this thesis has been an exciting, fun, frustrating and time intensive project for me that would not have been possible without the help of many people. Foremost, I thank my advisor, Dr. Jim Runkle, for sharing his vast knowledge of forests and various aspects of the natural world including woodcocks and wild flowers. His steady, cheerful approach allowed me to believe it was possible and avoid both nightmares and anxiety attacks. I am grateful to my committee members, Dr. Yvonne Vadeboncoeur and Dr. Don Cipollini, for their very useful suggestions regarding the design and scope of the project as well as their encouraging words. I greatly appreciated the help of Mike Enright from Five Rivers MetroParks, who got me started by marking locations of pawpaw patches on park maps and coordinated my field work with the park system. I am thankful for the people of Five Rivers MetroParks and the Ohio Department of Natural Resources who work to preserve and maintain the beautiful areas in which I conducted this research. Dr. Harry Khamis and Beverly Grunden from the Statistical Counsulting Center at Wright State illuminated the logistic regression statistic and provided guidance regarding the statistical analysis of the project. My husband, Mike Baumer, was either figuratively or literally at my side every step of the way. He is a field assistant 'extraordinaire' and I feel blessed and thankful for his constant support. My sons Alex and Craig were children when I started this journey in 1997. They listened patiently as I excitedly discussed my newly acquired knowledge and graciously worked as field assistants. I am particularly grateful to Craig, who will be studying computer engineering next year, for the frequent assistance that he offered in using the computer. 
Many students and friends spent hours helping me in the field. For assistance with the manipulative experiment, including setting up deer fencing, trenching, digging and planting seedlings, and hauling water, I would like to thank Katherine Barto, Stephanie Enright, Bri Hohman, Jim Milks, and Greg Seely. For assistance at my field sites, I would like to thank Alex Baumer, Craig Baumer, Megan Laux, and Damon Stachler. My supportive field assistants hiked to the study sites carrying all kinds of equipment, held measuring tapes, located flags, recorded data and provided congenial company even when they did not share my excitement nor were particularly fond of forest creatures with eight legs. Lastly, I will always be grateful to those who got me started: to Beth Kinsel, a fellow counseling professional, to Marcie Wendeln, my former neighbor and Wright State professor, and to Dr. Jim Amon of Wright State University who gave me the opportunity to begin thinking about shrubs and woodlands. 


\section{INTRODUCTION}

The emergence, growth, and survival of canopy tree seedlings is essential to forest regeneration. Disturbances, including canopy gap formation (Runkle, 1981, 1990;

McCarthy, 2001) and deer herbivory (Rooney and Dress, 1997; Frelich, 2002), have been extensively studied as processes that influence forest structure and composition. The presence of an understory layer also influences seedling establishment (Royo and Carson, 2006). Studies on forest understories have found reduced tree seedling growth and/or survival under Arecaceae (palms) (Denslow et al., 1991) and Gleicheniaceae (ferns) (Walker, 1994) in tropical environments, Poaceae (grasses) (Taylor et al., 1995) in forests in Japan and China, and Dennstaedtiaceae (ferns) (de la Cretaz and Kelty, 1999) in the Eastern United States. Forest understories composed of shrubs also impact seedling distributions (Beckage et al., 2000; Collier et al., 2002; Gorchov and Trisel, 2003; Lambers and Clark, 2003). The present study focuses specifically on the impact of a shrub understory in deciduous forests of the United States.

The presence of a shrub understory alters the environment required for tree seedling establishment both positively and negatively. Shrub canopies limit resources required for seedling establishment and survival. Shrubs reduce light levels on the forest floor (Beckage et al., 2000; Nilsen et al., 2001; Lei et al., 2002) and decrease soil moisture and nutrient levels (Putz and Canham, 1992; Nilsen et al., 2001). Litter accumulation (Beckage et $a l, 2000)$ and increased seedling predation by small mammals under shrubs (Rousset and Lepart, 2000) also create difficulties for seedling establishment. Shrubs can also facilitate seedling survival by reducing grazing pressures due to large mammals (Rousset and Lepart, 2000) and moderating abiotic conditions 
(Buckley et al., 1998). Whether shrubs are facilitative or competitive may depend on the life stage of the tree (Callaway and Walker, 1997). Shrubs have been shown to facilitate seed germination and emergence (Rousset and Lepart, 2000) but lower growth and survival at the seedling and sapling stages (Fagan and Peart, 2003; Lambers and Clark, 2003).

Shrub understories decrease seedling density, growth and survival (Beckage et al., 2000; Nilsen et al., 2001; Collier et al., 2002; Lei et al., 2002; Fagan and Peart, 2003; Gorchov and Trisel, 2003; Lambers and Clark, 2003). This effect has been found with invasive shrubs outside their native range, such as Lonicera maackii and Rhamnus frangula, as well as shrubs in their native range such as Rhododendron maximum, Buxus sempervirens and Juniperus communis. In the Southern Appalachians, where the effect of a $R$. maximum understory has been extensively studied, seedling densities for at least six canopy tree species were decreased under that species: Acer pennsylvanicum, Acer rubrum, Fraxinus americana, Quercus rubra, Tsuga canadensis, and Prunus serotina (Beckage et al., 2000, Nilsen et al., 2001; Lei et al., 2002; Lambers and Clark, 2003). An understory of L. maackii decreased both the number of species and seedling density (Collier et al., 2002), while removing the shoots of L. maackii increased the survival of four native tree species that were transplanted into plots with the shrub (Gorchov and Trisel, 2003).

While limitations in either light or moisture affect tree seedling growth and survival, competition for light may be the more important factor under a shrub canopy in mesic forests. Under the low light conditions of a closed canopy forest, competition for moisture and soil resources tends to have less of an effect on plant growth. At $2 \%$ full 
ambient sunlight, availability of soil resources (water and $\mathrm{N}$ ) was not related to growth measurements (Canham et al., 1996). Only as light levels increased did limitations in soil resources limit growth. Adequate soil moisture and nutrients also decrease the magnitude of below ground competition (Casper and Jackson, 1997). On a xeric site with nutrient poor soil, reducing root competition increased growth (Putz and Canham, 1992). However, on a more mesic site, only a combination of decreased competition for light and decreased root competition affected growth. In a study under L. maackii, above ground effects were generally more important than below ground effects (Gorchov and Trisel, 2003). Eliminating competition for light alone increased the survival of Acer saccharum (uncaged), Fraxinus americana, and Quercus rubra, while eliminating below ground competition increased survival for A. saccharum (caged to prevent deer browsing) and $P$. serotina only when combined with removal of above ground competition.

Limitations in resources as a result of a shrub canopy are likely to affect different species in different ways. Eastern forests are generally populated by a mixture of hardwoods that respond in species-specific ways to the spatial heterogeneity of light and soil resources found in mature woods. Shade-intolerant species are able to maximize whole-plant $\mathrm{CO}_{2}$ exchange in moderately low to high light, but have decreased survival in very low light related in part to high respiration rates (Walters and Reich, 2000). Acer saccharum, the dominant species in the study area, is very shade tolerant and may therefore be more likely than other less shade-tolerant species to survive under a shrub canopy.

Findings regarding shade tolerance as a factor in survival under shrubs have not been completely consistent. Shade tolerance was not related to seedling survival under $R$. 
maximum for A. rubrum, F. americana and Q. rubra (Lambers and Clark, 2003). In contrast, also under $R$. maximum, the relative order of survival of three species (Tsuga > Quercus $>$ Prunus) was related to shade tolerance (Lei et al., 2002). The survival of both Q. rubra and P. serotina was significantly correlated with the light environment while mortality of the more shade tolerant $T$. canadensis was attributed to the effect of litter accumulation. Under a canopy of $R$. frangula, the growth and/or the survival of seedlings of $A$. rubrum and $P$. strobus was decreased while seedlings of the more shade tolerant $A$. saccharum were not affected (Fagan and Peart, 2003).

Shrub understories in temperate forests have increased over the last half-century (Beckage et al., 2000; Collier et al., 2002). Fire suppression and large-scale tree die-offs due to disease have contributed to an increase in R. maximum and Kalmia latifolia in Appalachian forests (Monk et al. 1985). The creation of secondary forests from agricultural land and other anthropogenic disturbances such as the fragmenting of woodlots has contributed to an increase in the distribution and density of the exotic shrub, L. maackii (Deering and Vankat, 1999; Collier et al. 2002).

The native shrub, Asimina triloba (L.) Dunal (Annonaceae), pawpaw, is found in the understory of forests in eastern North America. Historically, fires set by Native Americans restricted pawpaw to moist areas (Larimore et al., 2003). Presently pawpaw is confined to more hydric sites in the northern portion of its geographical range but near the center of its range it is found in upland locations and hillsides, as well as in low, wet spots (Lagrange and Tramer, 1985). Pawpaw is a useful understory species to study as it has characteristics that may moderate its competition with tree seedlings. Pawpaw is not invasive and, although it reproduces clonally, clonal growth does not lead to excessive 
patch expansion (Hosaka et al., 2005). In contrast to L. maackii, the leaves of pawpaw develop slowly in mid- to late spring, allowing early season light to reach the forest floor. Pawpaw is deciduous, without the thick leaf litter of $R$. maximum. While densities of $L$. maackii and $R$. maximum have been reported at up to 6800 shrubs per hectare and 5000 to 17000 stems per hectare respectively (Trisel and Gorchov, 1994; Baker and Van Lear, 1998), densities for pawpaw are considerably less at 1800 to 5100 stems per hectare (Lagrange and Tramer, 1985).

This project explores the following questions: 1) what are the effects of pawpaw on the density of canopy tree seedlings? 2) does the presence of pawpaw differentially favor the survival of one tree species over another? 3) how are levels of light and moisture changed by the shrub's presence? 4) which has a bigger impact on seedling growth: competition for light or competition for soil resources?

I conducted a field study to measure density and survival of tree seedlings under and outside of a canopy of pawpaw and a manipulative study to investigate the role of above ground and below ground competition for resources. The following hypotheses were tested: 1) tree seedling density will be lower in plots under pawpaw than in plots outside of pawpaw; 2) the effect of pawpaw on survival will vary by tree species; 3) (a) light levels and (b) soil moisture will be lower in plots under pawpaw than in plots outside of pawpaw; and 4) above ground effects will influence growth and survival more than below ground effects. 


\section{METHODS}

\section{STUDY SITES}

The study was conducted in mature hardwood forests in the Dayton, Ohio (USA) area. The climate is a humid, temperate climate with hot summers and no dry season (Koppen climate classification: Cfa) (Oberlander and Muller, 1982). January temperatures during 2005 and 2006 averaged above 30 year norms (mean Jan. 05: 3.9 C, 7.2 C above normal; mean Jan. 06: -1.9 C, 1.3 C above normal). July temperatures during the period were very close to normal (Mean July 05: 24.2 C, 0.7 C above normal; mean July 06: 24 C, 0.5 C above normal). Precipitation was $115 \mathrm{~cm}$ in 2005 and 115.4 $\mathrm{cm}$ in 2006, both above the average yearly precipitation of $100.5 \mathrm{~cm}$ for 1971 to 2000 (National Oceanic and Atmospheric Administration, 2007). Soils in the study area are part of the Ohio Till Plain and were formed by glacial deposits. Soils are classified within Ohio Region 4 as Miamian-Kokomo-Eldean. This series consists of well-drained soils, $32 \%$ of which have $>3 \%$ organic matter in the top three inches and $>27 \%$ clay in the topsoil (Ohio Department of Natural Resources, 2007).

Plots were located in the following six sites:

Wright State University campus woods encompasses 80 ha located in Bath Township, Greene County, Ohio $\left(39^{\circ} 47^{\prime} \mathrm{N}, 84^{0} 03^{\prime} \mathrm{W}\right)$. The woods are composed of two secondary growth stands and one old-growth stand in which the two study sites were located. The older growth stand has probably been selectively cut and used for livestock grazing but was never cleared (DeMars and Runkle, 1992). The area is classified as an oak-sugar maple forest (Gordon 1969). Sugar maple dominates the old-growth stand with relative basal areas of 46-64\%; oaks (Quercus alba, Q. rubra, and 
Q. muehlenbergii) compose 20-37\% of the stand's relative basal area (Runkle et al., 2005). Other dominant species include Juglans nigra (black walnut), F. americana (white ash), Ulmus rubra (slippery elm), Tilia americana (basswood), P. serotina (black cherry), Carya cordiformis (bitternut hickory), and Carya ovata (shagbark hickory) (Runkle et al., 2005). The woods have a basal area of $30 \mathrm{~m}^{2} / \mathrm{ha}$, which is similar to other mature woods in Ohio (Runkle et al., 2005).

Englewood MetroPark comprises 792 ha located in Montgomery County, Ohio $\left(39^{\circ} 48^{\prime} \mathrm{N} 84^{0} 18^{\prime} \mathrm{W}\right)$. The park is a Five Rivers MetroPark that surrounds the Stillwater River. The study sites consist of mature mixed mesophytic hardwoods with canopy trees averaging $>38 \mathrm{~cm}$ dbh (Five Rivers MetroPark, 1999). Species composition includes Quercus spp. (oaks), Carya spp. (hickories), Fagus grandfolia (beech), A. saccharum (sugar maple), Fraxinus spp. (ash), Liriodendron tulipifera (yellow poplar), and Tilia americana (basswood) with no single genus dominating.

Aullwood Gardens is a 13 ha park that is part of and adjacent to Englewood MetroPark. The woods consist of old-growth, mixed mesophytic hardwoods (see def. above). Sites have been classified as 'old-growth' if the canopy trees average $>38 \mathrm{~cm}$ dbh, some trees average $>76 \mathrm{~cm}$ dbh and standing snags and large fallen logs are present (Five Rivers MetroPark, 1999). This area was enclosed with fencing to exclude deer in March 2003.

Twin Creek MetroPark is a 393 ha park located in Montgomery County, Ohio $\left(39^{\circ} 40^{\prime} \mathrm{N} 84^{0} 21^{\prime} \mathrm{W}\right)$, that straddles the Twin Creek. The study sites have been classified as old-growth oak-maple woods (Five Rivers MetroPark, 1999). Species composition is $\geq 25 \%$ sugar maple and $\geq 20 \%$ oaks (Five Rivers MetroPark, 1999). 
Caesar Creek State Park encompasses 3213 ha located in Warren County, Ohio $\left(39^{\circ} 29^{\prime} \mathrm{N} 84^{0} 04^{\prime} \mathrm{W}\right)$. The park surrounds an 1145 ha lake that was formed in 1978 when the Army Corps of Engineers impounded an area of the Caesar Creek valley to assist with flood control in the Little Miami River watershed. The study site is located in mature woods consisting of a mix of oak-hickory and beech-maple (Ohio Department of Natural Resources, Caesar Creek, Accessed February 2007).

Hueston Woods State Park is a 1455 ha park located in Preble County, Ohio $\left(39^{0} 34^{\prime} \mathrm{N}, 84^{\circ} 84^{\prime} \mathrm{W}\right)$. The study sites are located in a 67 ha old growth stand with an overstory dominated by beech and sugar maple. The site has been used extensively for research on forest dynamics (Moore and Vankat, 1986; Runkle, 2000; Kupfer and Runkle, 2003).

Maps of the study areas with site locations marked are in the Appendix.

\section{SPECIES DESCRIPTION}

Pawpaw is the northernmost member of the mostly neotropical family Custardapple (Annonaceae) consisting of about 130 genera and 2,300 species (Lagrange and Tramer, 1985). Pawpaw is a native American, deciduous shrub, with a single trunk, reaching six to $12 \mathrm{~m}$ tall. Simple, elongate leaves up to $25 \mathrm{~cm}$ long develop slowly in mid- to late spring, allowing early growing season light to reach the forest floor. Solitary, perfect flowers appear prior to the leaves. The large $(3 \mathrm{~cm})$, maroon flowers are strongly protogynous and pollinated by flies. . The fruit, a berry, is dull yellow, approximately $7.5-13 \mathrm{~cm}$ long and $2.5-4 \mathrm{~cm}$ wide, and ripens in the fall.

Pawpaw reproduces predominately by root sprouts initially forming concentric colonies that over time merge to form larger stands (Larimore et al., 2002). Lagrange 
and Tramer (1985) found stem density to be correlated with clump size and ranged from $0.18 / \mathrm{m}^{2}$ to $0.51 / \mathrm{m}^{2}$ in clumps between 357 and $482 \mathrm{~m}^{2}$, reflecting clonal reproduction. The identification of polymorphic markers in the DNA extracted from leaves collected from four pawpaw patches in Kentucky and one in Iowa suggests that patches are not totally clonal in structure (Bonney et al., 2001).

Lagrange and Tramer (1985) found that while flowers were abundant in all stands, fruit production varied significantly depending on geographic location. There was no fruit production in the Northern Ohio stands; fruit production reached a peak of 3.4 percent of the flowers in one of the stands in Kentucky. The lack of fruit set in Northern Ohio was attributed to the scarcity and isolation of pawpaw in that area and the protogynous flower rather than frost conditions.

Pawpaw is typically found in deciduous forests on slopes, ravines, floodplains, and along streams (Little, 1980; USDA, 2004). Geographical range is from southern Ontario and Western New York, south to Northwest Florida, west to East Texas and north to Southeast Nebraska (Little, 1980). It can be found at elevations up to $800 \mathrm{~m}$ in the Southern Appalachians. Pawpaw occupies a wider diversity of habitats in the middle part of its range than in the northern part of its range (Lagrange and Tramer, 1985). In Northern Ohio, pawpaw is restricted to wet sites such as swampy woodlands and floodplains but is found on hillsides as well as wet sites in Southern Ohio. In Tennessee, pawpaw occupies a variety of sites including open, rocky areas with thin soil and the forest understory. Pawpaw reaches its greatest height and girth on wet forested sites with sandy soil that provide good drainage. Upland sites that support pawpaw have no more than 34\% clay content (Lagrange and Tramer, 1985). 


\section{FIELD STUDY}

An investigation of the effects of pawpaw on tree seedlings was conducted at four sites: Twin Creek Reserve, Englewood Reserve and Wright State University Woods (2 sites). The sites consisted of upland forest that contained an understory layer of pawpaw and an adjacent area of similar overstory composition but without pawpaw or other shrubs. Sites were chosen to avoid areas that included L. maackii, an invasive shrub species commonly found in Ohio forests. These sites were either flat or gently sloping. At each site, four $5 \times 5 \mathrm{~m}$ plots were randomly placed, two within the pawpaw understory and two outside of pawpaw. To avoid pseudoreplication, data from the 4 plots were later collapsed into 2 groups (one inside and one outside) for the purpose of analysis.

Between July and September 2005, all tree stems $\leq 3 \mathrm{~m}$ tall within the plots were censused and tagged. Height, age, and species were recorded. Seedlings greater than one year were aged using bud scale scars. Light and moisture were measured once in each of the 4 plots and averaged to obtain one measurement for under pawpaw and one outside pawpaw for each site. Light was measured in the summer 2006 using a spherical densiometer (model $-\mathrm{C}$, Forest Densiometers). Measurements were taken facing south and below the pawpaw canopy, usually at a height of one meter. Soil moisture was measured within a three week period in late August and early September 2005 using a Kelway moisture meter (model HB2). Pawpaw stem density was recorded. Seedlings were recensused between June and September 2006 to determine survival status.

Additional data on stem density were obtained in 2006. Data were gathered from additional pairs of plots in Englewood Reserve and Twin Creek Reserve (one pair each), 
and new sites in Aullwood Garden (1 pair), Caesar Creek State Park (1 pair), and Hueston Woods State Park (4 pairs). Pairs of plots were selected as described above. Within each plot, five $1 \mathrm{x} 1 \mathrm{~m}$ subplots were randomly chosen and seedlings $\leq 3 \mathrm{~m}$ tall were counted. Pawpaw stem density in the $1 \mathrm{x} 1 \mathrm{~m}$ plots also was recorded.

Comparisons of stem density, light, and moisture inside and outside pawpaw were done using t-tests. Stem density comparisons were based on density $/ \mathrm{m}^{2}$. Light measurements were an estimation of overstory density in percent. Moisture was measured as the percent soil saturation relative to the field capacity of the soil. Kolmogorov-Smirnoff test for goodness of fit was used to compare stem age and height distributions inside and outside pawpaw.

Relationships between survival, pawpaw, site and species were examined using logistic regression. Using a dichotomous response variable, such as a seedling being alive or dead (i.e. survival), logistic regression computes an odds ratio. The odds of an event are the probability of one event divided by 1 minus the probability of the event. So if the probability of an event is $75 \%$ then the odds of the event occurring are $0.75 /(1-0.75)$ which equals 3. An odds ratio is the odds of one event occurring divided by the odds of another event occurring (Agresti, 1996). So in this study, the odds ratio computed by the statistic is the odds of a particular species surviving outside of pawpaw divided by the odds of the species surviving under pawpaw. When the odds ratio is greater than one, the odds of success (or, in this case, survival) are greater outside pawpaw than the odds of success (survival) under pawpaw for a particular species. The logistic regression statistic is an adjusted analysis that takes into account all of the variables in the model while survival percentages are simple descriptive statistics. 
All statistics were calculated using SAS 9.2 software.

\section{MANIPULATIVE EXPERIMENT}

Exploration of above-ground vs. below-ground competition was carried out in an area of the Wright State University woods with an understory of pawpaw. Using methodology adapted from Gorchov and Trisel (2003), the survival and growth of two year old transplanted A. saccharum seedlings were measured under two levels of root treatment and two levels of leaf treatment.

Eight $5 \mathrm{~m} \mathrm{x} 1 \mathrm{~m}$ plots were randomly established in a $25 \mathrm{~m} \times 10 \mathrm{~m}$ section of the woods that contained an understory of pawpaw. Two plots were established for each of the following four treatment conditions:

1. Tieback: The trunks of pawpaw plants both within the plot and shading the plot were securely tied back so that their leaves did not overhang the plot

2. Trenched: The soil along the perimeter of the plot was trenched to a depth of 30 $\mathrm{cm}$ to decrease root competition from pawpaw and other forest plants

3. Both: Pawpaw was tied back and the plot perimeter was trenched

4. Control: No manipulation.

Fifty seedlings were transplanted into each of the 8 plots in July 2005. The seedlings were gathered from another location in the Wright State University woods immediately prior to being transplanted. Any previously existing A. saccharum seedlings within the plots were tagged so that they would not be confused with the transplanted seedlings. The plants were watered immediately following transplanting. To protect against deer browsing the perimeter of the area was secured with a $2 \mathrm{~m}$ high deer exclosure. 
In early May 2006 the plots were censused for seedling survival. In September 2006 the transplanted seedlings were harvested to assess growth. Where available, 10 seedlings were randomly harvested from each plot (one of the control plots contained only 4 surviving seedlings). The seedlings were separated into root, stem and leaf components, air dried for 16 days (the time at which further weight loss due to moisture loss was negligible) and weighed.

The significance of root, leaf and root $\mathrm{x}$ leaf interactions on seedling survival and biomass was determined using ANOVA. Post-hoc Tukey's testing was used when applicable to identify which treatments differed from one another. 


\section{RESULTS}

\section{FIELD STUDY}

Seedling density. - Mean tree seedling density was $63 \%$ lower under pawpaw than not under pawpaw (5.23 stems $/ \mathrm{m}^{2}$ under pawpaw vs. $14.13 \mathrm{stems} / \mathrm{m}^{2}$ not under pawpaw) across all sampling sites $(\mathrm{t}=2.73, \mathrm{p}=0.0154)$. Pawpaw stem density averaged $1.78 \mathrm{stems} / \mathrm{m}^{2}$ for sites under pawpaw and was not related to tree seedling density (Pearson correlation coefficient $>0.05$ ). Differences in seedling density under pawpaw vs. not under pawpaw increased as the average seedling count of the site increased (Fig. 1). Sites with average seedling counts under 5 stems $/ \mathrm{m}^{2}$ had very small differences between seedling densities inside and outside of pawpaw. The largest difference was found at the site with the highest average seedling density. At that site, average stem density was 23 ; however, density averaged 37.8 seedlings $/ \mathrm{m}^{2}$ when pawpaw was not present and only 8.4 seedlings $/ \mathrm{m}^{2}$ under pawpaw. A best-fit linear regression of the data gives the equation $\mathrm{y}=1.07 \mathrm{x}-1.47$. The seedling count difference $(\mathrm{y})$ is approximately equal to the average seedling density $(\mathrm{x})$ for each site. Setting the seedling count difference equal to the average seedling density for each site, stem density outside of pawpaw is approximately three times stem density under pawpaw for the range of sites. Actual values for average stem density $/ \mathrm{m}^{2}$ for all study sites are given in Appendix table A1.

Height and age characteristics. — Stems under and outside pawpaw also differed in height and age characteristics. A greater percentage of stems outside pawpaw were taller and older than their counterparts under pawpaw. The biggest cumulative frequency difference in height was $9.6 \%$ ( $\mathrm{p} \leq 0.0026)$, obtained for stems $15 \mathrm{~cm}$ in height; $85.8 \%$ 
of stems not under pawpaw were $\leq 15 \mathrm{~cm}$ high while $95.4 \%$ of the stems under pawpaw were $\leq 15 \mathrm{~cm}$ high (Fig. 2A). The 16 to $20 \mathrm{~cm}$ height class composed $6.9 \%$ of stems not under pawpaw but only $2.8 \%$ of stems under pawpaw; the $>20 \mathrm{~cm}$ height class composed $7.3 \%$ of stems not under pawpaw and only $1.7 \%$ of stems under pawpaw. For age, the biggest cumulative frequency difference between stems under pawpaw and stems outside of pawpaw was $11.8 \%$ (p < 0.001) obtained for 3-year old stems; $92.4 \%$ of stems under pawpaw were $\leq 3$ years while $80.6 \%$ of stems not under pawpaw were $\leq 3$ years old (Fig 2B). The biggest difference for one size class was for stems $>3$ years old, representing $19.4 \%$ of all stems not under pawpaw but only $7.6 \%$ of all stems under pawpaw.

Resource availability. - Overstory density and moisture levels were measured at the four initial sites. Mean canopy density was $89.3 \%$ under pawpaw and $83.2 \%$ not under pawpaw ( $\mathrm{p}=0.037$ ) (Fig. 3A). Overstory density ranged from $85.96 \%$ to $92.72 \%$ under pawpaw and from $78.68 \%$ to $89.44 \%$ not under pawpaw. Overstory density was greater under pawpaw than outside pawpaw at all four sites. A large variation in the moisture level of sites not under pawpaw combined with the small sample size resulted in no significant difference in moisture levels $(\mathrm{p}=0.990)$. Moisture levels (measured as the percent soil saturation relative to the field capacity of the soil) under pawpaw ranged from $20 \%$ to $34.5 \%$ while moisture levels not under pawpaw ranged from $10 \%$ to $53.5 \%$ (Fig. 3B). Moisture levels were lower outside of pawpaw at 3 out of the 4 sites. Moisture levels at the fourth site exceeded levels at any of the other three sites regardless of pawpaw. The level outside of pawpaw at this site was much higher than any other site outside of pawpaw. 
Survival. - Logistic regression identified the relationships among survival, pawpaw, species and site to determine if the effect of pawpaw differentially favors the survival of one species over another. The analysis was performed using three species, A. saccharum, Fraxinus spp., and P. serotina, which combined composed $92 \%$ of the sample (A. saccharum, $65 \%$; Fraxinus spp., $16 \%$, P. serotina, $11 \%$ ). One of the four sites (WSU2) was dropped from the analysis because too many cells (parameter combinations) were empty. Using the complete model, a significant interaction was found between species and site $(\mathrm{p}=0.007)$ and the interaction between species and pawpaw approached significance $(\mathrm{p}=0.0605)$. The model was then run by species with

the following results: The presence of pawpaw was a significant factor in the survival of A. saccharum and P. serotina, but not of Fraxinus spp. (Table 1). The odds of survival for $P$. serotina were 3.2 times greater outside of pawpaw than under pawpaw. The odds of survival for A. saccharum were 1.44 times greater outside of pawpaw than under pawpaw (Table 2). Site was a significant factor in the survival of A. saccharum and Fraxinus spp. but was not significant for $P$. serotina. The percentages of surviving seedlings by site and species are given in Table 3 .

\section{MANIPULATIVE EXPERIMENT}

Survival. - Survival of the transplanted seedlings was not significantly related to either the leaf treatment or the root treatment or the interaction of the two. The small sample size as well as large within group variation contributed to the nonsignificant finding. Although the differences were not significant, the highest average survival rates were for plants with both leaf and root treatments (59\%) and the lowest average survival rates were for the control (37\%). Survival with just leaf treatment was higher than 
survival with just root treatment (57\% v. $46 \%)$ and approximated the survival rate of plants receiving both treatments (59\%) (Fig. 4). Actual values for the number of surviving A. saccharum seedlings in each treatment are given in Appendix table A2.

Seedling Biomass. — The total mass of the seedling (leaf, stem, and root) was significantly higher in the absence of both leaf and root competition (Fig. 5 and Table 4). The interaction of the leaf and root treatments was significant. When either treatment was conducted by itself, total biomass was similar to the control (Tukey's test). Leaf biomass increased significantly following the leaf treatment but not the root treatment. The interaction between leaf and root treatment approached significance $(\mathrm{p}=0.08)$. Although the leaf biomass was highest when both the leaves of the pawpaw were tied back and the soil was trenched, the means were not significantly different among groups (Tukey's test). Root biomass was significantly higher for trenched seedlings. The interaction between the root and leaf treatments was significant. Root biomass was not significantly related to the leaf treatment. Seedlings with both treatments had significantly higher root mass than seedlings with only one treatment. The control was intermediate, not significantly different from any other treatment (Tukey's test). The stem biomass was not related to either the leaf treatment or the root treatment, nor was the interaction of the root and leaf treatments significant. Actual values for the mean weight $(\mathrm{g}) /$ plant for total seedling biomass, leaf biomass, root biomass, and stem biomass for the four treatments are given in Appendix table A3. 


\section{DISCUSSION}

The results indicate that pawpaw does affect tree seedling establishment. I will address several specific hypotheses about the nature of these effects. My results supported Hypothesis 1 that seedling density is lower under pawpaw than in plots outside pawpaw. Seedling density under pawpaw averaged $63 \%$ less than in plots outside pawpaw. In all but one of the 14 plots, seedling density was lower under pawpaw than in an adjacent area that did not contain a shrub understory. This result mirrors patterns of seedling distributions found within and outside other shrub canopies. Seedling densities were 25 to $49 \%$ lower under R. maximum than not under it (Lambers and Clark, 2003). Under L. maackii, seedling densities were $68 \%$ lower than outside the shrub (Collier et al., 2002). Clearly a shrub canopy can lower tree seedling densities.

My results supported Hypothesis 2 that the effect of pawpaw on survival varies by tree species. Pawpaw had a much larger effect on the survival of $P$. serotina than on the survival of A. saccharum and did not affect the survival of Fraxinus spp.. The odds of survival for $P$. serotina were three times higher outside of pawpaw than under pawpaw, while the odds of survival of A. saccharum were about one and one half times higher outside than under. The differing effects of pawpaw on A. saccharum and P. serotina are likely related to the difference in shade tolerance between the two species. Shade tolerance involves a trade-off between growth under high light conditions and survival under low light conditions (Kobe et al., 1995). While A. saccharum grows slowly relative to $P$. serotina in high light, it survives more readily than $P$. serotina in low light (Kobe et al.,1995). This allows A. saccharum to survive under pawpaw even though light levels are only half of levels found in closed canopy, late successional forests (Cole 
and Weltzin, 2005). Although results from other studies regarding shade tolerance as a factor in survival under shrubs have not been completely consistent, when species with widely varying shade tolerances have been compared, shade tolerance appears to be important. Highly shade-intolerant $P$. serotina was less likely to survive under $R$. maximum than $T$. canadensis or $Q$. rubra (Lei et al., 2002) while highly shade-tolerant $A$. saccharum was more likely to survive under $R$. frangula when compared with A. rubrum and P. strobus (Fagan and Peart, 2003).

My results support Hypothesis 3a that light levels, as measured by overstory density, will be lower in plots under pawpaw than in plots outside of pawpaw. By midto late spring, the large leaves of pawpaw significantly decrease light availability on the forest floor. In a deciduous forest in Tennesssee where understory light was about $20 \%$ of full ambient sunlight, light levels under pawpaw were reduced to 6-7 \% of ambient understory light (Cole and Weltzin, 2005). In comparison, light resources were significantly decreased under a canopy of $R$. maximum, yet they also tended to vary spatially. During the growing season, light levels (photosynthetically active radiation) were about $0.25 \%$ of full sunlight. However, some sites under $R$. maximum had higher light levels than sites outside the shrub canopy (Nilsen et al., 2001). Light from sunflecks (sudden, short interval increases in light intensity) also was both less frequent and less intense under a $R$. maximum canopy resulting in about 5 times more light from sunflecks outside the shrub canopy than under the shrub canopy.

The results do not support Hypothesis $3 b$ that moisture levels will be lower under pawpaw than outside of pawpaw. On the contrary, moisture levels under pawpaw were 
$6 \%$ greater than levels outside pawpaw for the three sites at which moisture levels were higher under pawpaw. Studies comparing moisture levels inside and outside of $R$. maximum canopies found differing results. One study found water availability to be $20 \%$ lower throughout the growing season under the shrub than outside of it (Nilsen et al., 2001). However, two other studies found no significant differences in moisture levels inside and outside the shrub canopy (Beckage et al., 2000; Clinton, 2003). Moisture levels tend to vary throughout the growing season. Given that the levels in this study were measured on a one-time basis, with a small sample size, the conclusions should be considered tentative.

My study does not support Hypothesis 4 that above ground effects of pawpaw will have more of a difference on survival and growth of A. saccharum seedlings than below ground effects. In general, a combination of above ground and below ground processes seemed to be important. Survival was not significantly influenced by either above ground or below ground competition or their interaction. However, eliminating both above ground and below ground competition or above ground competition alone tended to be more important than elimination of below ground competition. Seedlings were exposed to the treatment conditions for only one growing season, which may not have been a long enough time period to detect treatment effects on survival. Elimination of both above ground and below ground competition was also the key determinant in differences in total seedling biomass. Leaf biomass was driven by elimination above ground competition while root biomass was driven by the elimination of below ground competition. Leaf and root biomass were highest when both above ground and below ground effects of pawpaw were restricted. These results contrast with the results of a 
similar study conducted under L. maackii in which above ground effects were found to be more important (Gorchov and Trisel, 2003). The differing results may be related to the tree species studied. In the Gorchov and Trisel study, F. americana and Q. rubra responded more to the elimination of above ground competition. Acer saccharum responded more to the elimination of above ground competition when it was caged to prevent deer browsing, but to a combination of above and below ground competition when it was not caged (Gorchov and Trisel, 2003).

\section{RESOURCE LIMITATIONS}

My manipulative experiment explored mechanisms responsible for the decreased density and survival found in my field study. Because only A. saccharum seedlings were used, the results do not necessarily reflect how other species respond to the shrub. Above ground effects in the study can be attributed to competition for light. Tying back the stems of pawpaw eliminated shading from the pawpaw leaves and increased light levels near the forest floor. Trenching to a depth of $30 \mathrm{~cm}$ severed pawpaw roots and other sources of below ground competition. Because the study plots contained only pawpaw, tree seedlings, and some herbaceous species, the effect of trenching is primarily to eliminate the competition from pawpaw.

Plant growth and survival depend on both light and soil resources. Limitations in two or more resources are more likely to limit plant growth (Chapin et al., 1987). In this study, competition from the combination of above ground and below ground sources more often affected the planted A. saccharum seedlings than either above or below ground effects alone. This result suggests that pawpaw limits the availability of both 
light and soil resources. Releasing either light or soil resources alone was insufficient to increase growth because the seedling continued to respond to competition for the other resource.

Light levels under pawpaw are reduced to about $1 \%$ of full ambient sunlight (Cole and Weltzin, 2005). In comparison, closed canopy, late successional forests have light levels of about $2 \%$ of full ambient sunlight (Canham et al., 1994). Relationships between low light availability and low growth and/or high mortality have been found for many species (Kobe et al., 1995). In light conditions of $<1 \%$ full sun, radial growth for A. saccharum and Fraxinus grandfolia was less than $0.05 \mathrm{~cm} /$ year. The probability of mortality at less than $1 \%$ full sun was much greater for $F$. grandfolia than A. saccharum reflecting differences in shade tolerance. Seedling mortality rates under low light conditions have been closely related to shade tolerance classifications (Walters and Reich, 2000).

Because the strength of below ground competition is decreased under low light conditions and in moister soils, I expected that above ground competition would be the more important factor. Although light levels were significantly lower under pawpaw, below ground competition was still a factor. Precipitation levels during the study period were above average and the study was located on mesic sites. This may have reduced the strength of below ground competition but did not eliminate it.

Responses to limitations in soil resources are also species specific. Reducing root competition by trenching had little effect on A. rubrum seedlings but increased survival of Cornus florida (Horn, 1985). A. saccharum and Q. rubra showed only minor differences in root growth when soil resources varied while A. rubrum and P. strobus 
responded with increased shoot growth relative to root growth under high soil resource levels and increased root growth relative to shoot growth in low soil resource conditions. (Canham et al., 1996). In contrast, A. saccharum seedlings in this study allocated more resources to root growth when below ground competition was restricted.

Other mechanisms, including alleopathy, seed limitations, seed predation, and litter accumulation have been implicated as reasons for the decreased density of tree seedlings under shrubs. These reasons are not likely to account for the effect of pawpaw. Experiments testing for alleopathic properties that used an aqueous leaf extract of pawpaw on Arabidopsis thaliana seeds (unpublished data, D. Cipollini and R. Stevenson, 2007) and ones that used soil collected from under pawpaw and Microstegium vimineum seeds resulted in no inhibitory effects (Cole and Weltzin, 2005). Additionally the National Data Plant Center lists pawpaw as not having allelopathic properties (USDA, 2004). Given that studies under R. maximum canopies have found that the shrub does not limit seed rain or the seed bank (Lei et al., 2002) and pawpaw presents a more open canopy than $R$. maximum, there is no reason to suspect that seed limitations under pawpaw exist. Increased seedling predation by small mammals occurs under $B$. sempervirens and J. communis (Rousset and Lepart, 2000) and R. maximum (Beckage et al., 2000). However, the single stem architecture of pawpaw probably does not provide the additional protective cover that leads to increased seed predation. Finally, litter accumulation is a factor with the thick, evergreen leaves of $R$. maximum but pawpaw leaves readily decompose and do not bury seedlings. 


\section{FOREST DYNAMICS}

Despite the fact that pawpaw does not possess many of the qualities that would characterize it as an aggressive competitor, seedling densities under pawpaw were reduced by similar amounts as under L. maackii and R. maximum. Even on very productive sites, with high seedling densities outside of pawpaw, stem densities under pawpaw were severely constrained. As a group, stems under pawpaw differed in height and age characteristics from their counterparts outside of pawpaw. A larger percentage of stems under pawpaw were younger and shorter suggesting that differences in mortality outside and under pawpaw manifest themselves within three years of seedling emergence. Using even the most conservative estimates for mortality from my data, it is unlikely that more than a couple of hardy individuals will survive under pawpaw to reach the canopy. The height of the pawpaw canopy will also be a factor in long term survival. The pawpaw canopy in my study ranged from about $1.5 \mathrm{~m}$ at some sites to over $3.5 \mathrm{~m}$ at other sites. A seedling that is able to emerge from the understory canopy sooner will likely have an increased chance of survival.

Shrub canopies reduce the survival of a variety of species. Survival of planted $Q$. rubra seedlings over a three year period was reduced by about $40 \%$ (Nilsen et al., 2001). Mortality of planted Q. rubra, P. serotina, and T. canadensis was up to five times greater under $R$. maximum over a three year period (Lei et al., 2002). Naturally occurring $Q$. rubra and Quercus prinus seedlings had an $81 \%$ mortality rate under $R$. maximum but only a $28 \%$ mortality rate outside of $R$. maximum over a two year period (Lei et al., 2002). Using estimates of mortality derived from growth data and published growth- 
mortality relationships, it was estimated that Rhamnus frangula increases seedling mortality by about $50 \%$ (Fagan and Pert, 2003).

Differences in seedling survival rates by species suggest that the relative abundance of the dominant species will be altered under pawpaw. The odds of survival of shade-intolerant $P$. serotina, which comprised $16 \%$ of the study sample, were reduced enough that survival to canopy height under pawpaw would be very unlikely. In contrast, Fraxinus spp. survival was not affected by pawpaw and could therefore increase in relative abundance. Shade tolerant $A$. saccharum was less affected by pawpaw than P. serotina; given it comprised $65 \%$ of the study sample it will remain the dominant species.

Pawpaw may also decrease the likelihood of tree seedling establishment in canopy gaps. Canopy gaps create temporary increases of light, moisture and nutrients required for tree establishment. Canopy disturbance caused by the death of one to several trees is sufficient for canopy replacement (Runkle, 1982). Yet, in Appalachian forests, light levels doubled with the creation of an intermediate size gap outside of $R$. maximum but did not increase beneath $R$. maximum even with gap formation (Beckage et al., 2000). When light levels under $R$. maximum increased with gap formation, the increase was statistically significant, but not likely to be biologically important (Clinton, 2003). Gap formation increased the density of $A$. rubrum seedlings but only when $R$. maximum was not present (Beckage et al., 2000). The growth of A. rubrum and P. strobus was reduced under a cover of $R$. frangula in intermediate-size gaps. However, seedling survival and growth were higher in gaps than outside the gaps regardless of shrub cover (Fagan and Peart, 2003). 


\section{PAWPAW UNDERSTORY DYNAMICS}

At my study sites, pawpaw formed a dense, nearly monodominant understory layer that did not exclude herbaceous species. Royo and Carson (2006) suggest that a species can be considered a 'recalcitrant understory layer' when it shares one or more of these characteristics (1) it is denser, with greater vegetation cover and lower diversity, than was common in the forest in the past, (2) it results in conditions that alter and slow succession of many tree species, or (3) it resists displacement by other species and remains intact for decades. My results found that pawpaw meets the second criterion of this definition. Some evidence also suggests that pawpaw both persists in the understory and is increasing in prevalence although how this differs from historical norms is not well delineated. No patch extinction was found during a three year study in Maryland, even among patches containing only two or three stems (Hosaka et al., 2005). Furthermore, stem natality was greater than stem mortality in nearly all patches studied and new stems grew as vigorously as old stems. Pawpaw in mesic upland forest in Illinois increased in density and size at one location but at two other sites the populations persisted but varied in size over the past 40 years (Larimore et al., 2003). Pawpaw populations at those sites were suffering from canker disease at the time of the study. Pawpaw density also increased in a beech-hemlock forest in Alabama over a 15 year period (Gunasekaran et al., 1992).

Because pawpaw persists once it is established, it may be able exploit disturbances such as increased deer herbivory and tree diseases to expand. In $53 \%$ of the studies reviewed by Royo and Carson (2006), the formation of an understory layer was 
linked to a combination of overstory disturbance and either changes in fire frequencies or increases in herbivory. Pawpaw is unpalatable to deer (USDA, 2001) so it does not experience the same pressure of elevated herbivory as tree seedlings. This may allow existing patches to expand clonally in areas where canopy regeneration is declining. Emerald ash borer is an exotic insect pest that is killing ash trees in several states and Canada as well as Ohio (MacFarlane and Meyer, 2005). Like R. maximum, which was able to take advantage of the death of chestnut trees to expand (Monk et al., 1985), pawpaw may increase if the ash borer results in a decline in the ash population.

\section{FUTURE RESEARCH}

The current study leaves a number of unanswered questions and suggests opportunities for further research. The roles of light and moisture were not well defined with the methods used in this study. Light and moisture were measured only on a one time basis in the field study and no measurements were taken in the manipulative study. Trenching, however, was useful to determine the effect of below ground resources as it produced differential responses and allowed exploration of the combined effect of all soil resources rather than only moisture. Expanding direct measurements of light and moisture would be helpful in understanding the mechanisms responsible for decreased tree seedlings under pawpaw.

Little is known about the prevalence of pawpaw in forests of various sizes and ages. In the presence of frequent fires it may have been confined to moister areas although this is probably not true currently. Under what circumstances and at what rate pawpaw colonies expand has not been studied. Similarly, the rate of establishment of 
new colonies is not known. Given that pawpaw decreases density and survival of canopy tree seedlings, a greater understanding of its place in the understory is warranted. 


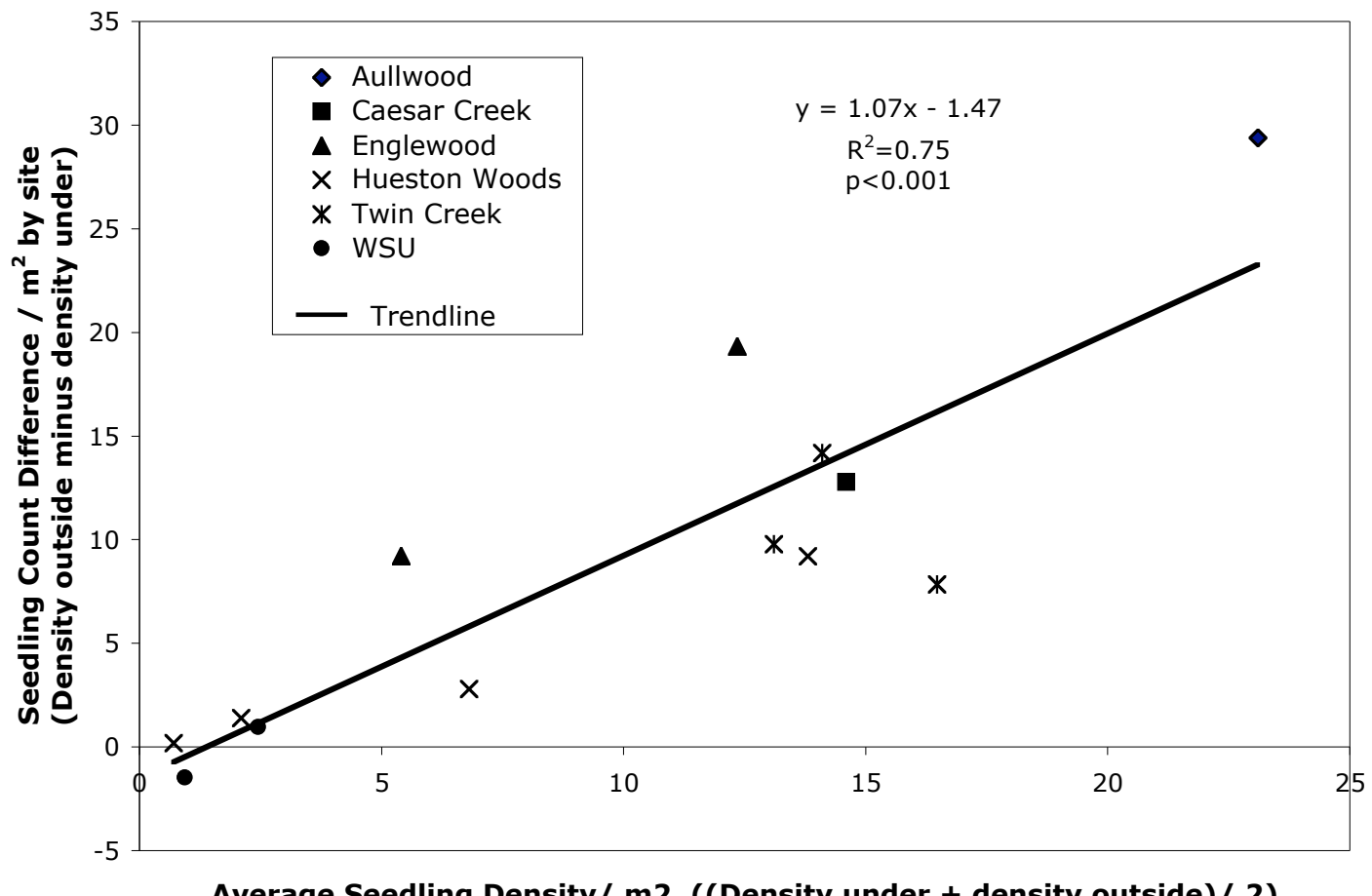

Average Seedling Density/ m2 ((Density under + density outside)/ 2)

FIG. 1.-Average tree seedling density v. differences in tree seedling densities outside and under pawpaw for 11 sites at six locations. The trendline is the best-fit linear regression of the data with the equation $\mathrm{y}=1.07 \mathrm{x}-1.47$. 

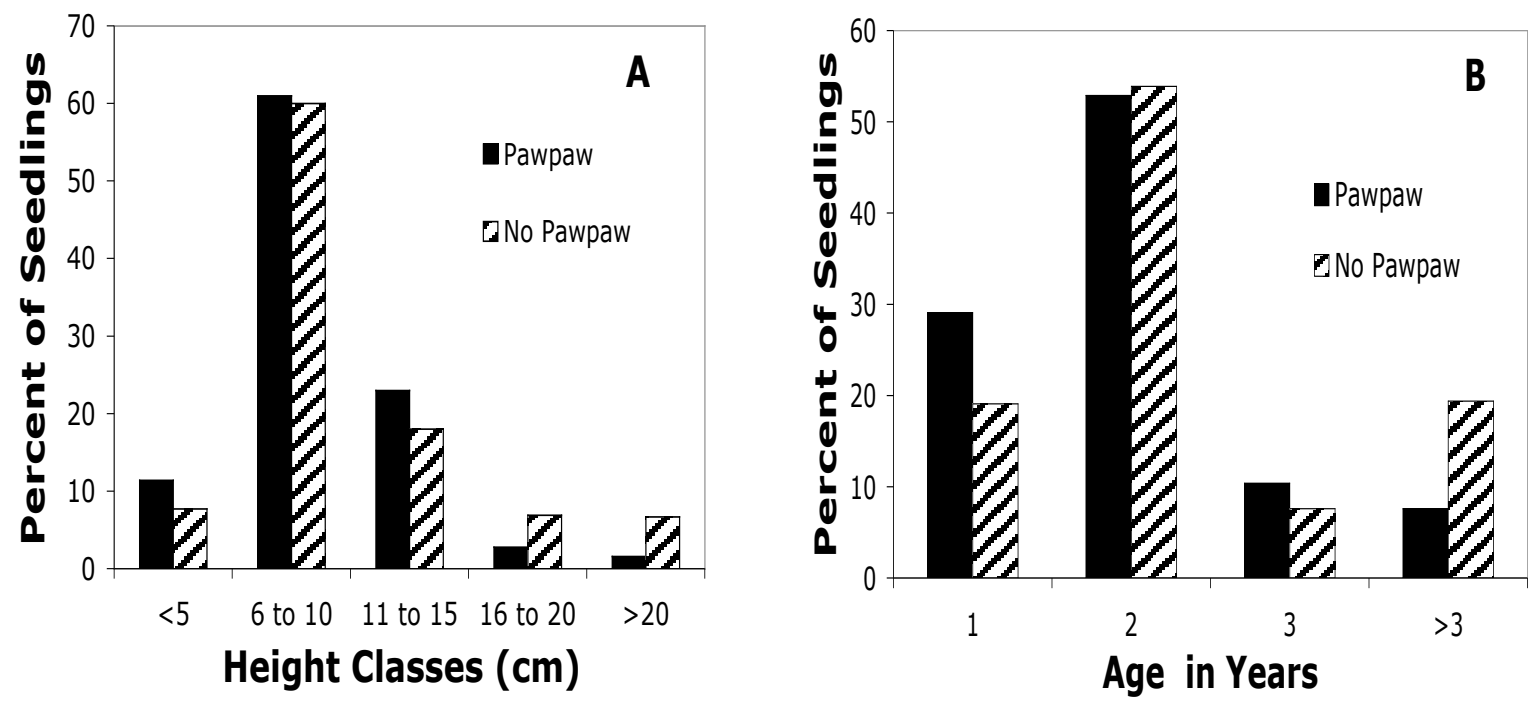

FIG. 2.-Comparisons of tree seedling percentages by A) height and B) age classes between under pawpaw ( $n=754$ for height, 750 for age) and not under pawpaw ( $n=688$ for height, 686 for age) at four sites (Twin Creek Reserve, Englewood Reserve, and Wright State University woods (two sites)). 

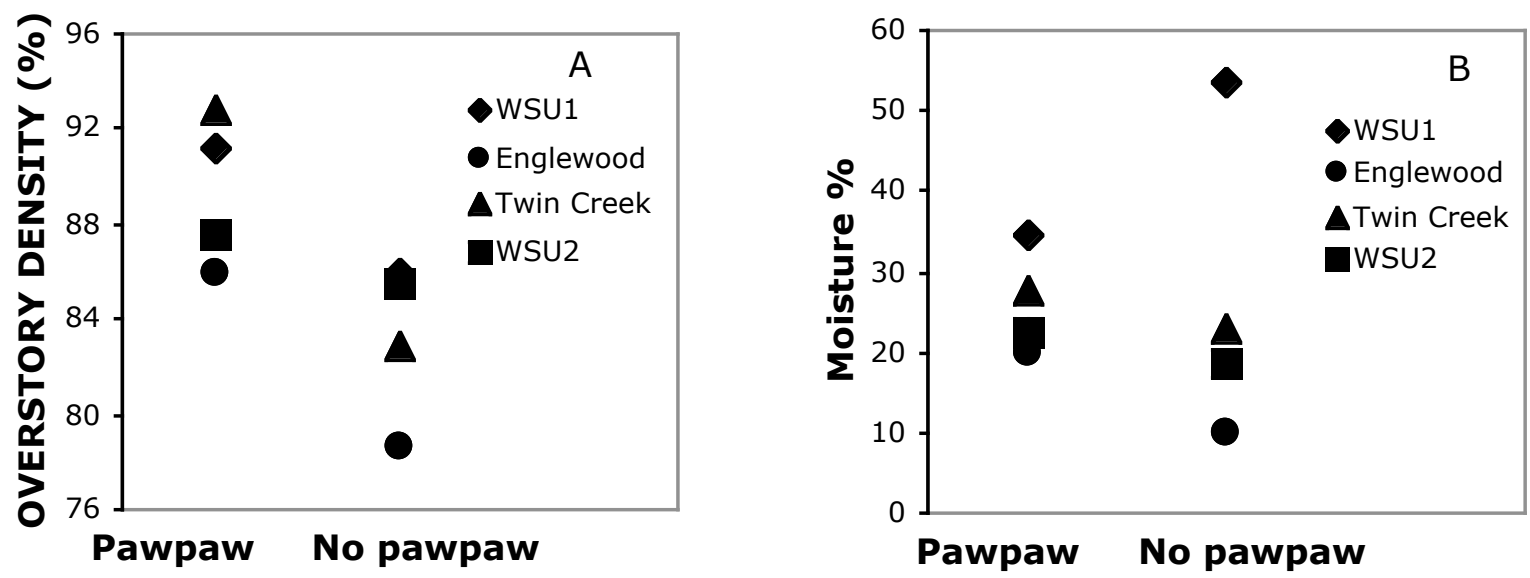

FIG, 3.- Comparisons of (A) overstory canopy density and (B) moisture levels under and not under pawpaw. Overstory canopy density and soil moisture were measured once in each of two plots and averaged to obtain one measurement for under pawpaw and one measurement for outside pawpaw for each of the four sites. 


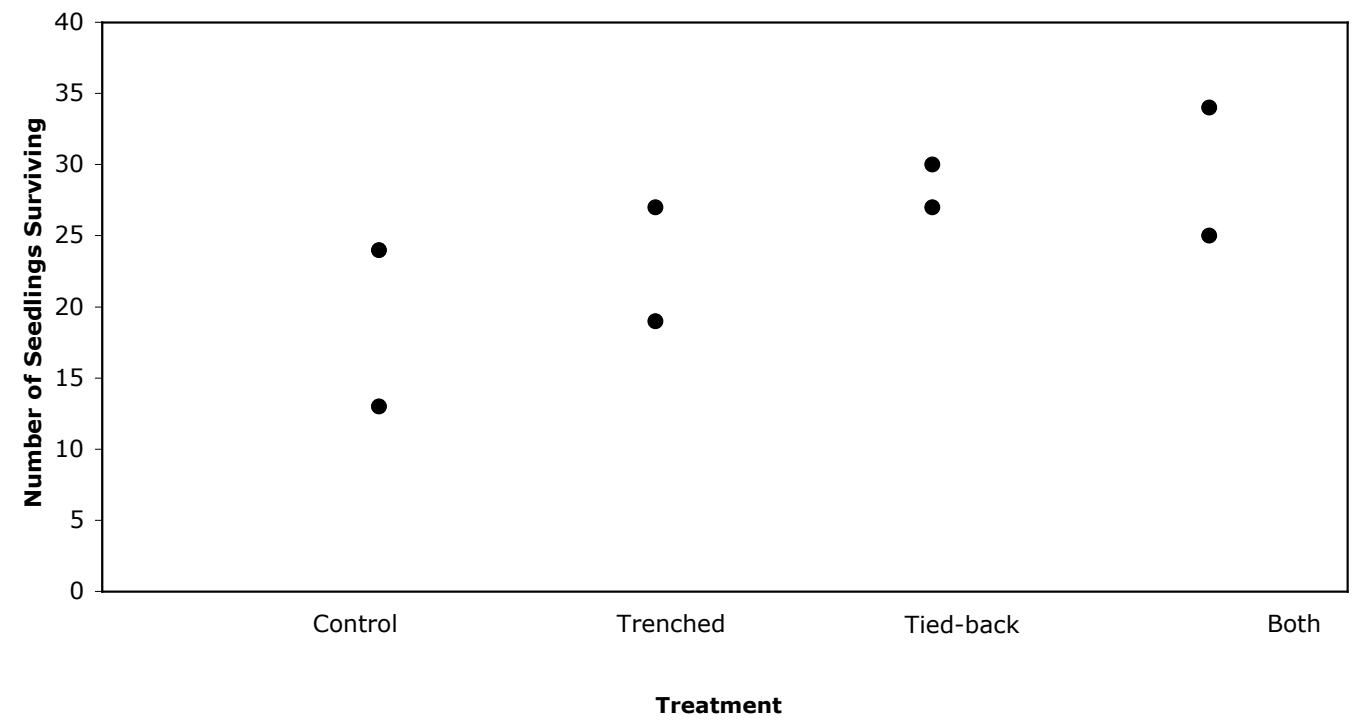

FIG. 4.-Effects of trenching and tie-back of pawpaw on survival of Acer saccharum seedlings. $\mathrm{N}=50$ seedlings/ replicate for two replicates/treatment. 

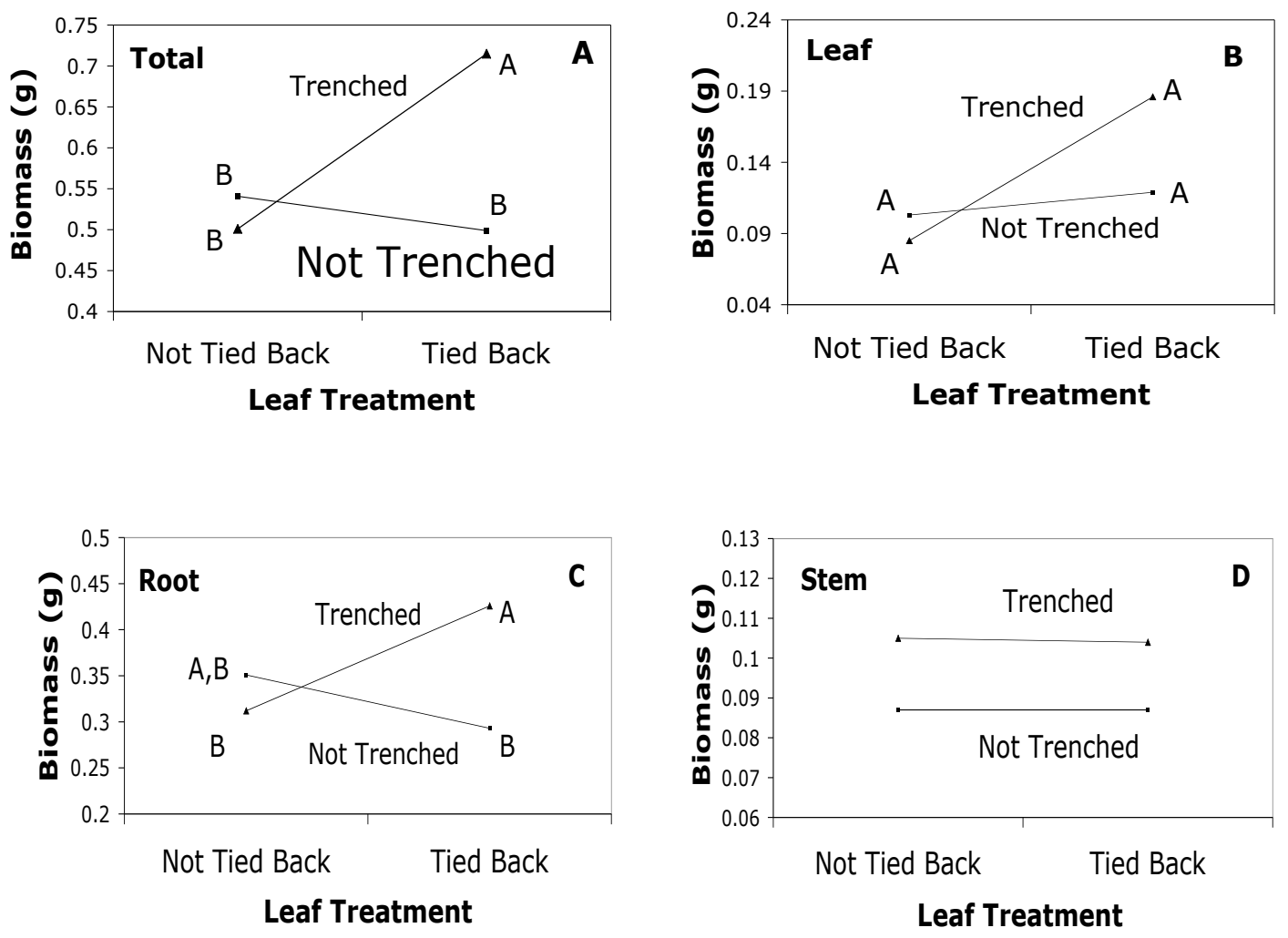

FIG. 5.-Effects of trenching and leaf treatment on A) total seedling biomass, B) leaf biomass, C) root biomass and D) stem biomass. $\mathrm{N}=20$ seedlings except for Not tied back + not trenched, which $=14$. Letters are shown for cases in which ANOVA was significant; treatments without a common letter are significantly different $(\mathrm{P}<0.05$, Tukey test). 
TABLE 1. - Summary of the relationships among seedling survival, pawpaw, species, and site from logistic regression analysis.

\begin{tabular}{llcr}
\hline Effect & DF & Wald Chi-Square & P \\
\hline Pawpaw & 1 & 14.327 & 0.0002 \\
Species & 2 & 47.340 & $<0.0001$ \\
Site & 2 & 4.081 & 0.1300 \\
Species x Pawpaw & 2 & 5.609 & 0.0605 \\
Pawpaw x Site & 2 & 0.7971 & 0.6713 \\
Species x Site & 4 & 14.1549 & 0.0068 \\
\hline
\end{tabular}


TABLE 2. - Summary of the effects of pawpaw and site by species on survival of tree seedlings from logistic regression analysis.

\begin{tabular}{lllcc}
\hline \hline Species & Effect & DF & Wald Chi-Square & P \\
\hline A. saccharum & Pawpaw & 1 & 4.6784 & 0.0305 \\
& Site & 2 & 142.8521 & $<0.0001$ \\
Fraxinus spp. & Pawpaw & 1 & 0.9736 & 0.3238 \\
& Site & 2 & 26.2446 & $<0.0001$ \\
P. serotina & Pawpaw & 1 & 14.1397 & 0.0002 \\
& Site & 2 & 5.2470 & 0.0725 \\
\hline
\end{tabular}


TABLE 3.-Percent annual survival from 2005 to 2006 (original $\mathrm{N}$ in parentheses).

\begin{tabular}{|c|c|c|c|c|c|c|}
\hline \multirow[t]{2}{*}{ Site } & \multicolumn{2}{|c|}{ A. saccharum } & \multicolumn{2}{|c|}{ P. serotina } & \multicolumn{2}{|c|}{ Fraxinus spp. } \\
\hline & Under & Out & Under & Out & Under & Out \\
\hline WSU 1 & $25.3(75)$ & $25.9(81)$ & (5) & $25 \quad(4)$ & $-(0)$ & $9.1 \quad(55)$ \\
\hline Englewood & 38.1 (97) & $48.3(261)$ & (2) & 50 & $75(8)$ & $63.0 \quad(46)$ \\
\hline Twin Creek & $78.1(260)$ & $85.6(111)$ & $44.2(147)$ & $71.4(70)$ & $80(10)$ & (5) \\
\hline
\end{tabular}


TABLE 4. - Summary of 2-way ANOVAs of the growth response of Acer saccharum seedlings to leaf treatments. $\mathrm{DF}=1$ for each effect, so sum of Squares $(\mathrm{SS})=$ Mean Squares (MS). Since effects were fixed, F's were obtained by dividing by the Error MS.

\begin{tabular}{llcrc}
\hline Dependent variable & \multicolumn{1}{c}{ Effect } & SS & F & P \\
\hline Total Biomass $(\mathrm{g})$ & Leaf treatment & 0.015 & 8.64 & 0.04 \\
& Root treatment & 0.016 & 9.05 & 0.04 \\
& Root x Leaf & 0.033 & 18.96 & 0.01 \\
& & & & \\
Leaf Biomass $(\mathrm{g})$ & Leaf treatment & 0.007 & 10.06 & 0.03 \\
& Root treatment & 0.001 & 1.71 & 0.26 \\
& Root x Leaf & 0.004 & 5.21 & 0.08 \\
& & & & \\
Stem Biomass $(\mathrm{g})$ & Leaf treatment & $<0.001$ & 0.0 & 0.97 \\
& Root treatment & 0.0006 & 1.81 & 0.25 \\
& Root x Leaf & $<0.001$ & 0.0 & 0.97 \\
& & & & \\
Root Biomass $(\mathrm{g})$ & Leaf treatment & 0.002 & 2.8 & 0.17 \\
& Root treatment & 0.004 & 7.72 & 0.05 \\
& Root x Leaf & 0.015 & 26.40 & $<0.01$ \\
\hline
\end{tabular}




\section{Welcome to Aullwood Garden MetroPark}

For decades, this living work of art has touched visitors emotionally and spiritually with its diversity and abundance of floral displays, towering trees and serenity.

Aullwood Garden became part of Five Rivers MetroParks in 1977 when Mrs. John Aull donated her 32-acre country garden and home, which are now on the Ohio State and National Historic Registries, to MetroParks. A previous gift to the National Audubon Society in 1955 established the nearby Aullwood Audubon Center and Farm. Both endowments have given the public countless opportunities to learn about and experience the outdoors.

We invite you to stroll the grounds of this very special garden. Visit often and discover the beauty of color, texture and form.
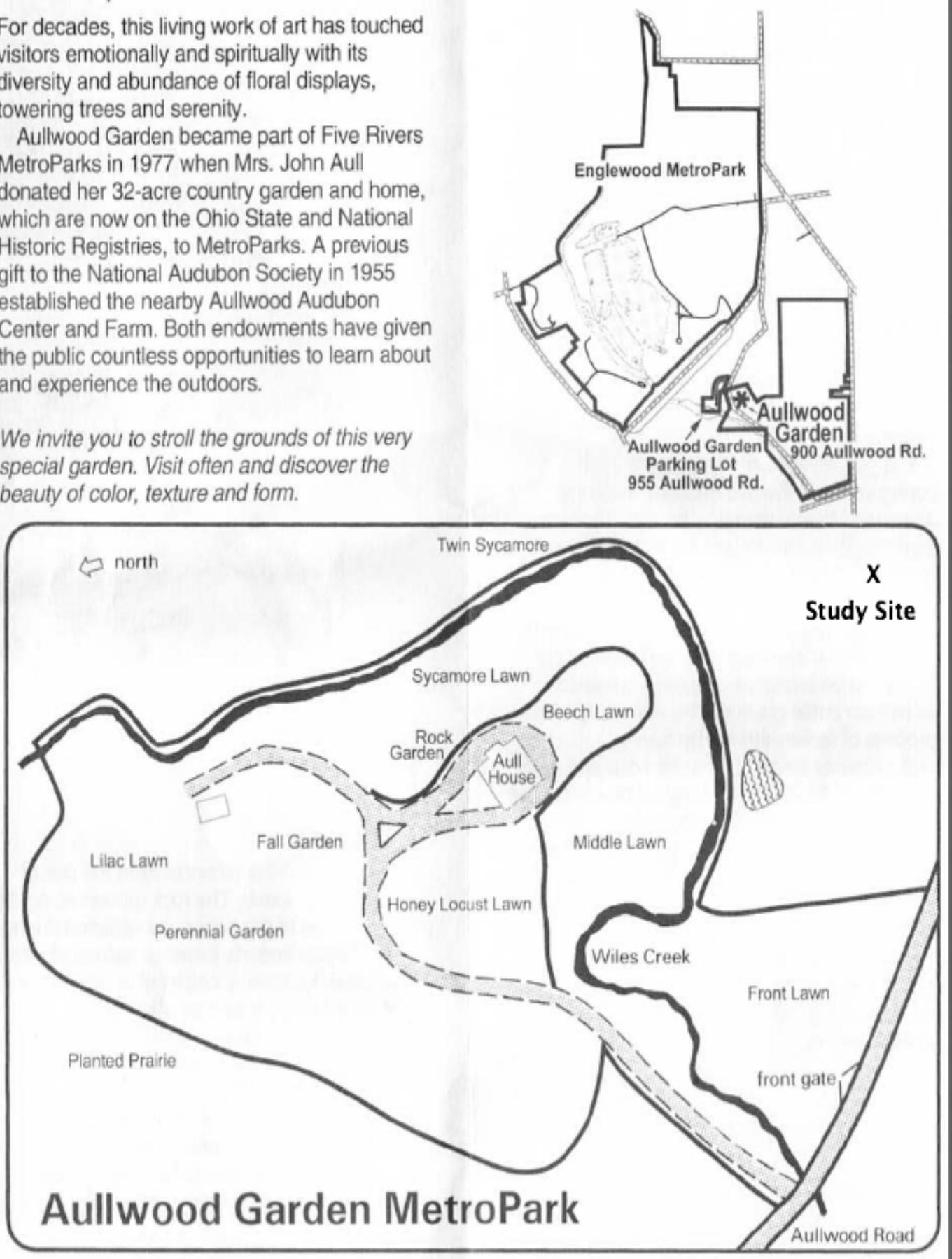


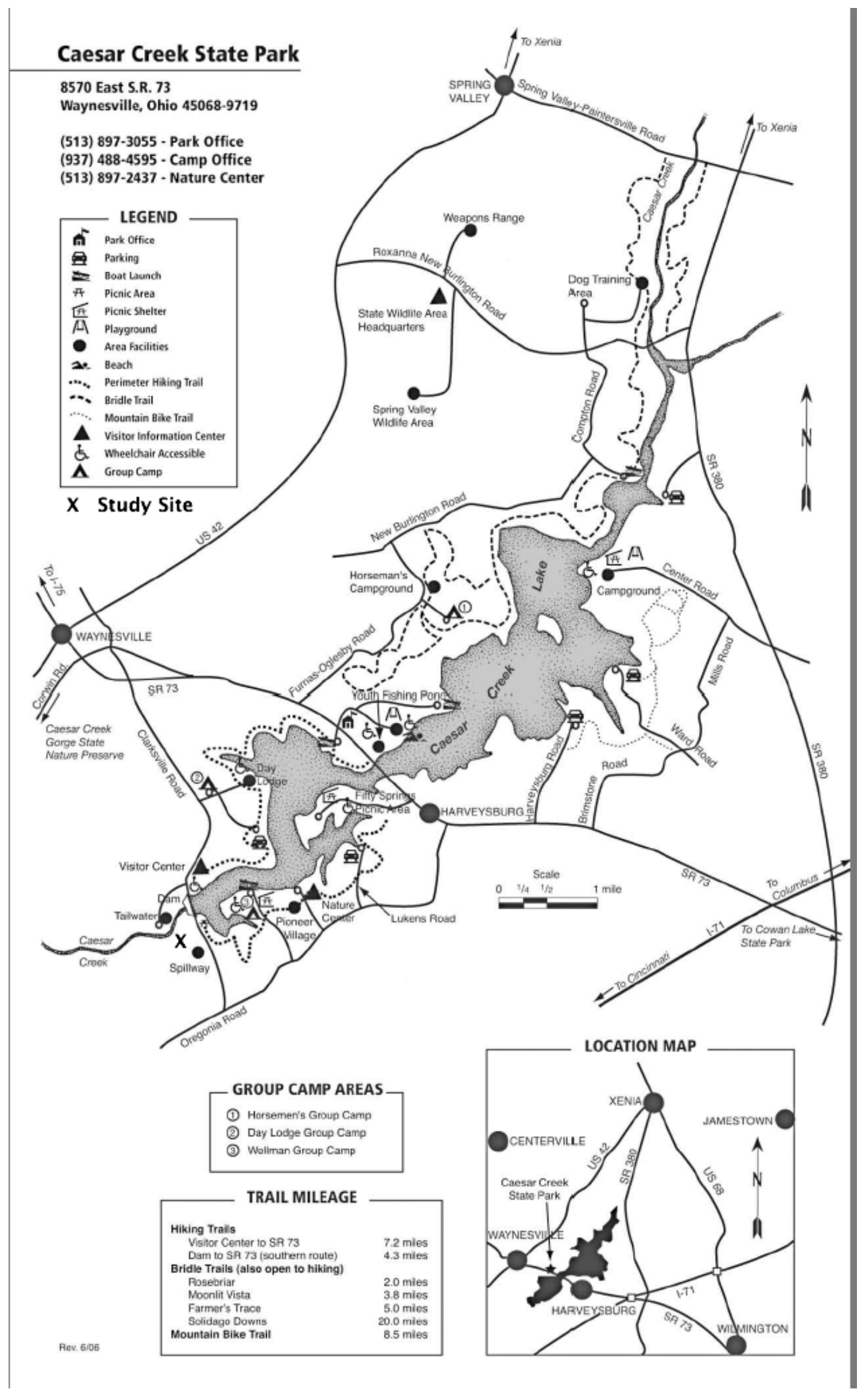




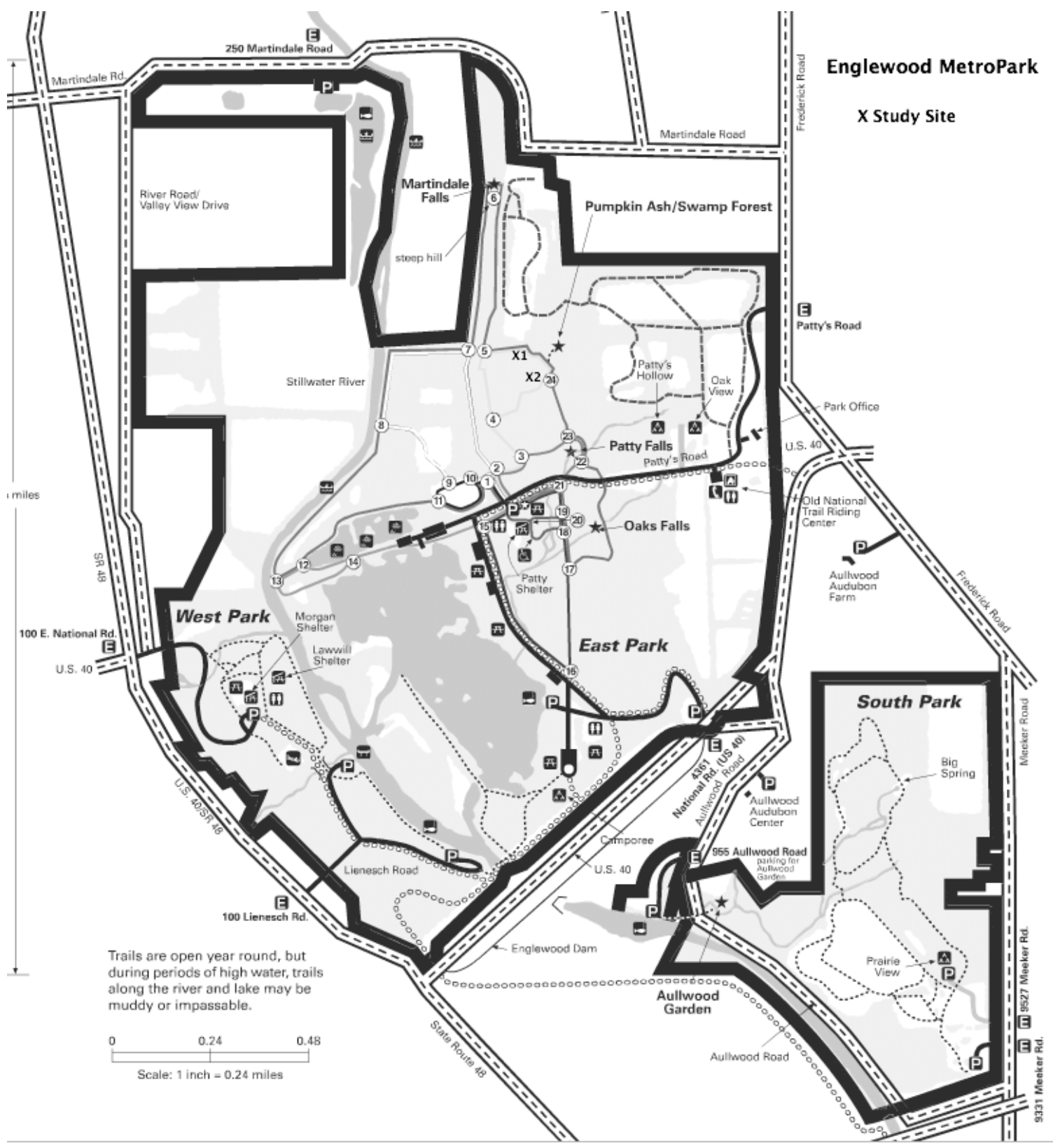




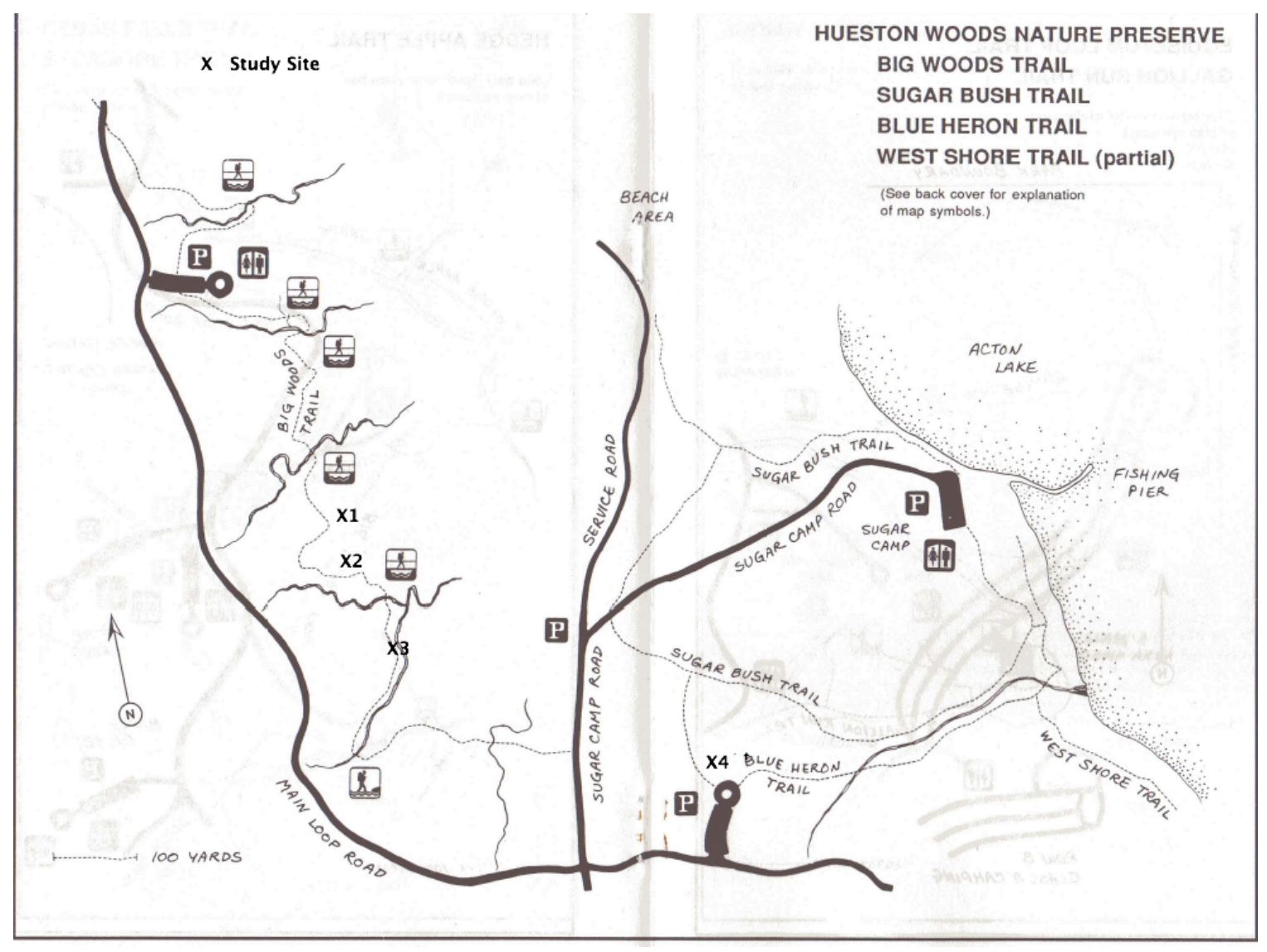




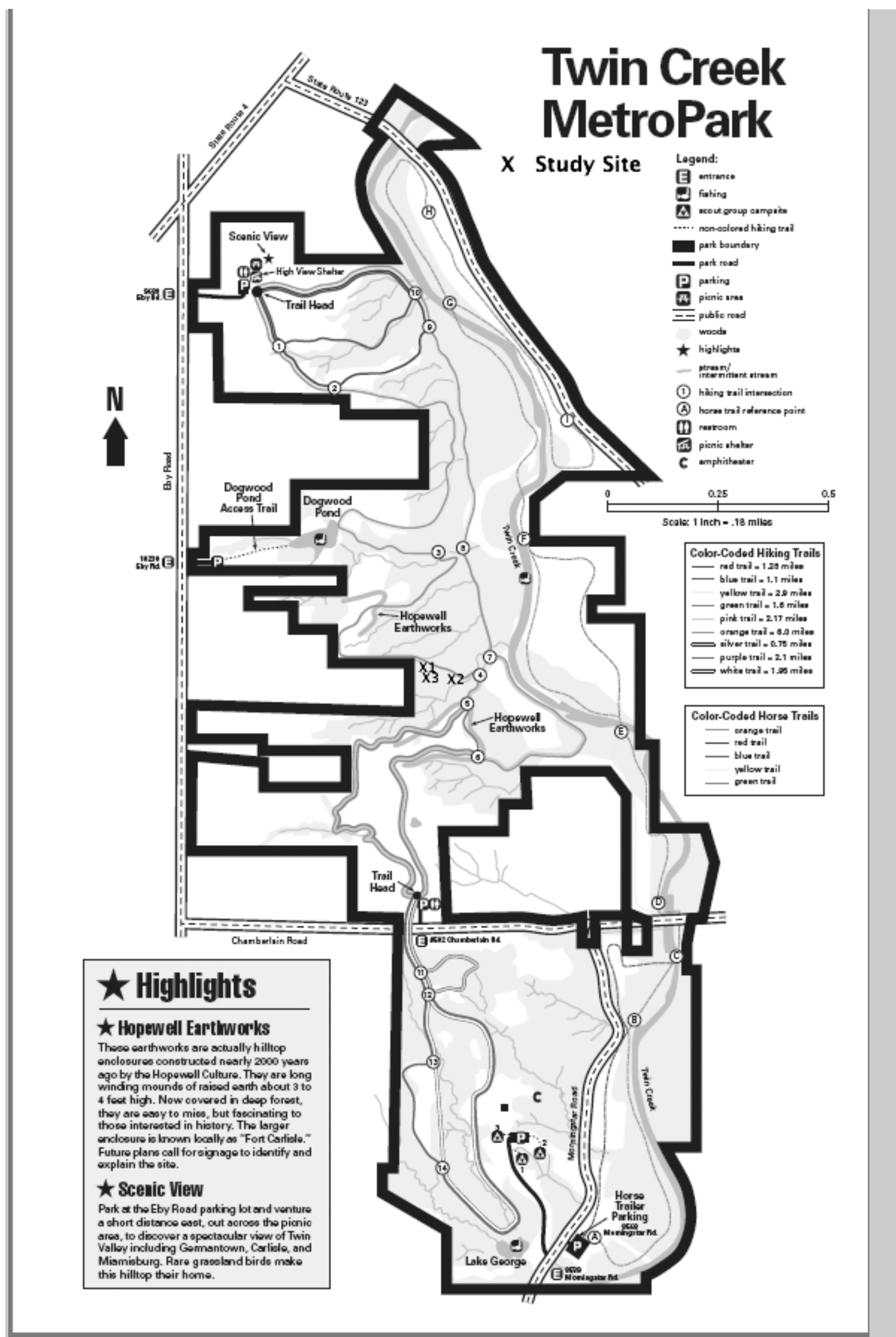




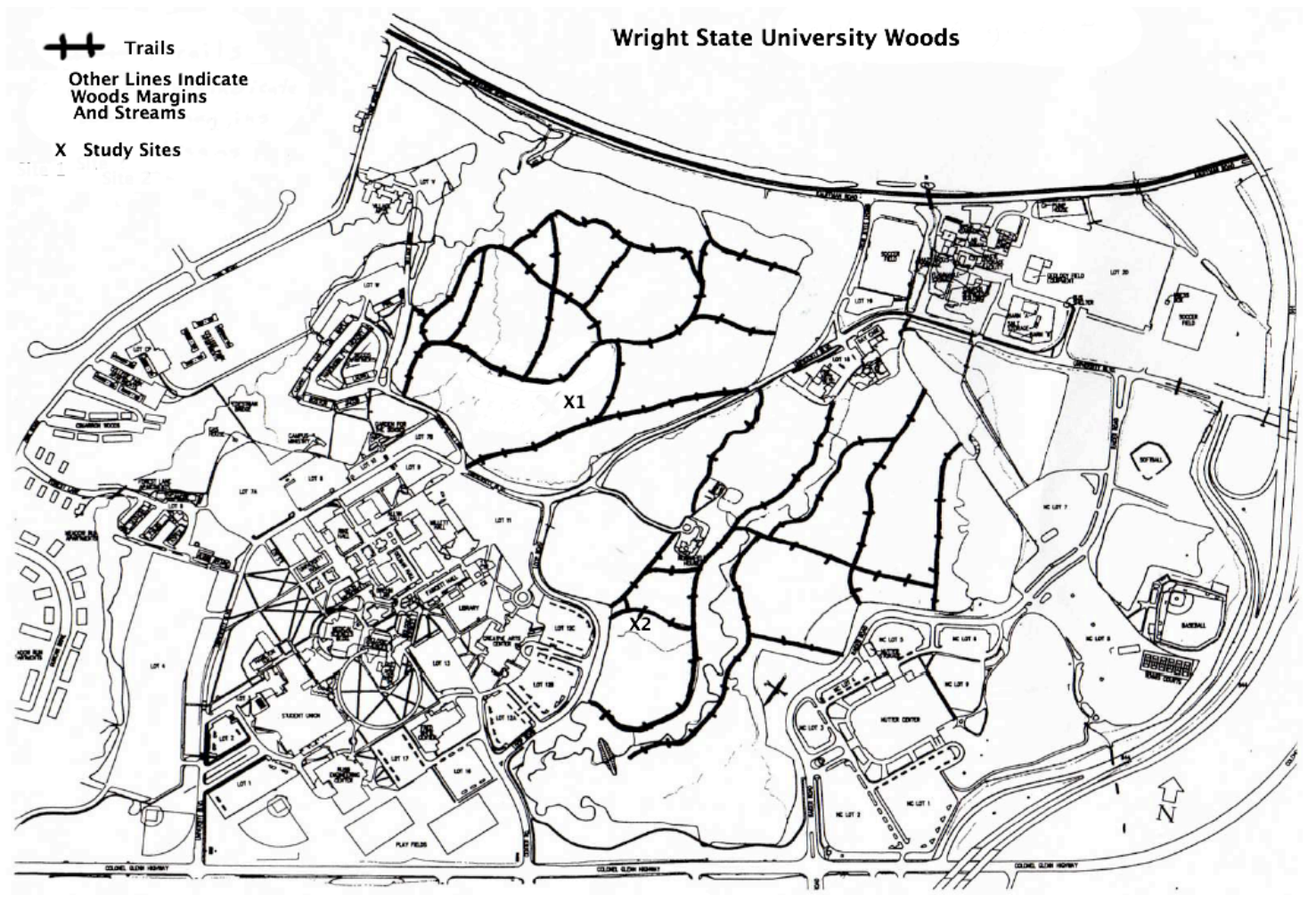


TABLE A1 . Average stem density $/ \mathrm{m}^{2}$ for all study sites.

\begin{tabular}{lcccc}
\hline Site & $\begin{array}{c}\text { Outside } \\
\text { Pawpaw }\end{array}$ & $\begin{array}{c}\text { Under } \\
\text { Pawpaw }\end{array}$ & $\begin{array}{c}\text { Site } \\
\text { Average }\end{array}$ & $\begin{array}{c}\text { Outside - } \\
\text { Inside }\end{array}$ \\
\hline Aullwood & 37.8 & 8.4 & 23.1 & 29.4 \\
Caesar Creek & 21 & 8.2 & 14.6 & 12.8 \\
Englewood 1 & 22 & 2.68 & 12.34 & 19.32 \\
Englewood 2 & 10 & 0.8 & 5.4 & 9.2 \\
Hueston W. 1 & 2.8 & 1.4 & 2.1 & 1.4 \\
Hueston W. 2 & 8.2 & 5.4 & 6.8 & 2.8 \\
Hueston W. 3 & 18.4 & 9.2 & 13.8 & 9.2 \\
Hueston W. 4 & 0.8 & 0.6 & 0.7 & 0.2 \\
Twin Creek 1 & 20.4 & 12.54 & 16.47 & 7.86 \\
Twin Creek 2 & 21.2 & 7 & 14.1 & 14.2 \\
Twin Creek 3 & 18 & 8.2 & 13.1 & 9.8 \\
WSU 1 & 2.94 & 1.96 & 2.45 & 0.98 \\
WSU 2 & 0.2 & 1.66 & 0.93 & -1.46
\end{tabular}


TABLE A2. Number of surviving A. saccharum seedlings for two replicates of four treatments (initial $\mathrm{N}_{0}=50$ ).

\begin{tabular}{lcr}
\hline \hline & Surviving Seedlings \\
\hline Control & 24 & 13 \\
Tie Back & 27 & 30 \\
Trenched & 27 & 19 \\
Both & 25 & 34 \\
\hline
\end{tabular}


TABLE A3 . Mean weight (g)/ plant for total seedling biomass, leaf biomass, root biomass, and stem biomass for four treatments and two plots/treatment. Values are based on 20 plants except for the control, which is based on 14 plants.

\begin{tabular}{lllll}
\hline \hline & Total & Leaf & Root & Stem \\
\hline Control & 0.541 & 0.103 & 0.351 & 0.087 \\
Tie Back & 0.499 & 0.119 & 0.293 & 0.087 \\
Trenched & 0.501 & 0.085 & 0.312 & 0.105 \\
Both & 0.715 & 0.186 & 0.426 & 0.104 \\
\hline
\end{tabular}




\section{LITERATURE CITED}

Agresti, A. 1996. An introduction to categorical data analysis. John Wiley \& Sons, Inc., New York.

BAKER, T. T., AND D. H. VAN LEAR, 1998. Relations between density of rhododendron thickets and diversity of riparian forests. Forest Ecology and Management 109: 21-32.

Beckage, B., J. S. Clark, B. D. Clinton and B. L. Haines, 2000. A long-term study of tree seedling recruitment in southern Appalachian forests: the effects of canopy gaps and shrub understories. Can J. For. Res. 30: 1617-1631.

Bonney, T.M., S.B. Crabtree, K.W. Pomper and R.L. Geneve. 2001. Assessment of genetic diversity and clonality within native pawpaw patches using RAPDs. HortScience 36: 533.

BuCKLEY, D. S., T. L. SHARIK AND J. G. IsEbRANDS. 1998. Regeneration of Northern Red Oak: positive and negative effects of competitor removal. Ecology 79 (1): 65-78.

Callaway, R. M. And L. R. Walker. 1997. Competition and facilitation: a synthetic approach to interactions in plant communities. Ecology 78 (7): 1958-1965.

Canham, C. D., A. C. Finzi, S. W. Pacala And D. H. Burbank. 1994. Causes and consequences of resource heterogeneity in forests: interspecific variation in light transmission by canopy trees. Can. J. For. Res. 24: 37-349.

Canham, C. D., A. R. Berkowitz, V. R. Kelly, G. M. Lovett, S. V. Ollinger and J. SCHNURR. 1996. Biomass allocation and multiple resource limitation in tree seedlings. Can. J. For. Res. 26: 1521-1530.

CASPER, B.B. AND R.B. JACKSON, 1997. Plant competition underground. Annu. Rev. Ecol. Syst. 28: 545-570.

Chapin III, R. S., A. J. Bloom, C. B. Field And R. H. Waring. 1987. Plant responses to multiple environmental factors. BioScience. 37 (1): 49-57.

CLINTON, B. D. 2003. Light, temperature, and soil moisture responses to elevation, evergreen understory, and small canopy gaps in the southern Appalachians. Forest Ecology and Management. 186: 243-255.

Cole, P.G., AND J.F. WELtzIN. 2005. Light limitation creates patchy distribution of an invasive grass in eastern deciduous forests. Biol. Invasions 7: 477-488.

Collier, M. H., J. L. VAnKaT AND M. R. HugeS. 2002. Diminished plant richness and abundance below Lonicera maackii, an invasive shrub. Am. Midl. Nat, 147: 6071.

DE la CRetAZ, A. L., AND M. J. KelTy. 1999. Establishment and control of hay-scented fern: a native invasive species. Biol. Invasions, 1: 223-236.

DEMARS, B. G. AND J. R. RUNKLE. 1992. Groundlayer vegetation ordination and sitefactor analysis of the Wright State University Woods (Greene county, Ohio). Ohio J. Sci. 92 (4): 98-106.

Denslow. S. J., E. Newell, AND A. M. Ellison. 1991. The effect of understory palms and cyclanths on the growth and survival of inga seedlings. Biotropica, 23: 225234.

DeERing, R. H. AND J. L. VAnKat. 1999. Forest Colonization and Developmental Growth of the Invasive Shrub Lonicera maackii. Am. Midl. Nat, 141:43-50. 
Ebinger, J., D. O'Connell, S. Turner, F. Catchrole, and W. McClain. 1997. Vegetation survey of Elkhart Woods, Logan County, Illinois. Castanea 62: 7481.

Edgin, B. 2003. Vascular flora of Big Creek Woods Memorial Nature Preserve, Richland County, Illinois. Trans. Ill. State Acad. Sci. 96: 179-192.

FAGAN, M. E. AND D. R. PEART. 2003. Impact of the invasive shrub glossy buckthorn (Rhamnus frangula L.) on juvenile recruitment by canopy trees. Forest Ecology and Management 194:95-107.

Five Rivers MetroParKs, 1999. Forest Size Classes and Plant Community Mapping. Inhouse reports. Dayton, Ohio.

FrELICH, L. E. 2002. Disturbance regimes and forest dynamics. Cambridge University Press, Cambridge, UK.

Gorchov D. L. AND D. E. TRISEL. 2003. Competitive effects of the invasive shrub, Lonicera maackii (Rupr.) Herder (Caprifoliaceae), on the growth and survival of native tree seedlings. Plant Ecology. 166:13-24.

Gordon, R. B. 1969. the natural vegetation of Ohio in pioneer days. Bull. Ohio Biol. Surv. 3: 1-109.

gunasekaran, M., D. J. Weber, S. Sanderson And M. M. Devall. 1992. Reanalysis of the vegetation of Bee Branch Gorge Research Natural Area, a Hemlock-Beech community on the Warrior River Basin of Alabama. Castanea. 57 (1): 34-45.

Hosaka, N., S. GOMEZ, N. Kachi, J. F. Stuefer and D. R. Whigham. 2005. The ecological significance of clonal growth in the understory tree, Pawpaw (Asimina triloba). Northeastern Naturalist. 12 (1): 11-22.

HoRn, J.C. 1985. Responses of understory tree seedlings to trenching. Am. Midl. Nat. 114: $252-258$.

KUPFER, J. A. AND J. R. RunKLE, 2001. Edge-mediated effects on stand dynamic processes in forest interiors: a coupled field and simulation approach. Oikos. 101: 135-146.

Kobe, R.K., S.W. PaCAla, J.A. Silander, And C.D. CANHAM. 1995. Juvenile tree survivorship as a component of shade tolerance. Ecol. Appl. 5: 517-532.

LAGRANGE, R. L. AND E. J. TRAMER. 1985. Geographic variation in size and reproductive success in the paw paw (Asimina triloba). Ohio J. Sci. 85 (1): 40-45.

LAMBERS, J. H. R. AND J. S. ClARK. 2003. Effects of dispersal, shrubs, and densitydependent mortality on seed and seedling distributions in temperate forest. Can.J. For. Res., 33: 783-795.

Larimore, R. L., D. T. Busemeyer And J. E. Ebinger. 2003. Pawpaw, Asimina triloba (L.) Dunal (Annonaceae), in the Prairie Peninsula of Illinois, USA. Nat. Areas J. 23: $356-361$.

Lei, T. T., S. W. Semones, J. F. Walker, B. D Clinton and E. T. Nilsen. 2002. Effects of Rhododendron Maximum thickets on tree seed dispersal, seedling morphology, and survivorship. International Journal of Plant Science, 163 (6): 991-1000.

LitTLE, E. L. 1980. National Audubon Society field guide to North American trees, Eastern ed. Alfred A. Knopf, New York. p. 446-447.

MCCARTHY, J. 2001. Gap dynamics of forest trees: a review with particular attention to boreal forests. Environ. Rev. 9: 1-59. 
MacFarlane, D.W. AND S.P. MEYER. 2005. Characteristics and distribution of potential ash tree hosts for emerald ash borer. For. Ecol. Manage. 213: 15-24.

MonK, C. D., D. T. MCGINTY AND F. J. DAY, JR. 1985. The ecological importance of Kalmia latifolia and Rhododendron maximum in the deciduous forest of the southern Appalachians. Bull. Torrey Bot. Club, 112: 187-193.

MoORE, M. R. AND J. L. VANKAT. 1986. Responses of the herb layer to the gap dynamics of a beech-maple forest. Am. Midl. Nat. 115: 336-347.

NATIONAL OCEANIC AND ATMOSPHERIC ADMINISTRATION's NATIONAL WEATHER SERVICE ForCAST OfFICE, WiLMINGTON, OHIO. $<$ http://www.erh.noaa,gov/iln/lcdpage.htm>. Accessed Feb. 9, 2007.

Nilsen, E. T., B. D. Clinton, T. T. Lei, O. K. Miller, S. W. Semones and J. F. WALKER, 2001. Does Rhodedendron maximum L. (Ericaceae) reduce the availabilitity of resources above and belowground for canopy tree seedlings? Am. Midl. Nat., 145:325-343.

Oberlander, T. M. AND R. A. Muller. 1982. Essentials of physical geography today. Random House, New York. p. 192-193, 481-483.

Ohio Department of Natural Resources. Caesar Creek State Park. <http://www.dnr.state.oh.us/parks/parks/caesarck.htm>. Accessed Feb. 10, 2007.

OHIO DEPARTMENT OF NATURAL RESOURCES. DIVISION OF SOIL AND WATER CONSERVATION. <http://www.dnr.state.oh.us/soilandwater/soils/soilregl.htm, Accessed Feb. 9, 2007.

PutZ, F. E. AND C. D. CANHAM. 1992. Mechanisms of arrested succession in shrublands: root and shoot competition between shrubs and tree seedlings. For. Ecol. Manage. 49: 267-275.

RoONEY T. P. AND W. J. DRESS. 1997. Species loss over sixty-six years in the ground layer vegetation of Heart's Content, an old-growth forest in Pennsylvania USA. Nat. Areas J. 17: 297-305.

Rousset, O. AND J. LEPART. 2000. Positive and negative interactions at different life stages of a colonizing species (Quercus humilis). J. Ecology 88: 401-412.

Royo, A. A. AND W. P. CARSON. 2006. On the formation of dense understory layers in forests worldwide: consequences and implications for forest dynamics, biodiversity, and succession. Can. J. For. Res. 36:1345-1362.

RUNKLE, J. R. 1981. Gap regeneration in some old-growth forests of the eastern United States. Ecology. 62: 1041-1051.

RUNKLE, J. R. 1982. Patterns of disturbance in some old-growth forests of the eastern United States. Ecology. 63: 1533-1546.

RunKLE, J. R. 1990. Gap dynamics in an Ohio Acer-Fagus forest and speculations on the geography of disturbance. Can. J. For. Res. 20: 632-641.

RunkLE, J. R. 2000. Canopy tree turnover in old-growth mesic forests of eastern North American. Ecology. 81: 554-567.

Runkle, J. R., L. A. Fairbanks, K. H. Armstrong, T. S. Campbell and A. L. ESPENSCHIED-REILY. 2005. Changes in older and younger woods in west-Central Ohio. Ohio J. Sci. 105 (5):116-124.

WELTZIN, J.F., 2005. Light limitation creates patchy distribution of an invasive grass in eastern deciduous forests. Biol. Invasions, 7: 477-488. 
TAYLOR, A. H., Z. QIN, AND J. LIU.1995. Tree regeneration in an Abies faxoniana forest after bamboo dieback Wang Lang Natural Reserve, China. Can. J. For. Res. 25: 2034-3039.

TRISEL D. E. AND D. L. GoRCHOV. 1994. Regional distribution, leaf phenology, and herbivory of the invasive shrub, Lonicera maackii. Bulletin of the Ecological Society of America 75: 231-232.

WALKER, L. R. 1994. Effects of fern thickets on woodland development on landslides in Puerto Rico. J. Veg. Sci. 5: 525-532.

Walters M. B., AND P. B. REICH. 2000. Trade-offs in low-light $\mathrm{CO}_{2}$ exchange: a component of variation in shade tolerance among cold temperate tree seedlings. Functional Ecology. 14: 155-165.

USDA, National Resources Conservation Service. 2004. The PLANTS Database, Version $3.5<\mathrm{http}$ ://plants.usda.gov/java/profile?symbol=ASTR Accessed March 2. 2007. 